\title{
Seismic behaviour of traditional timber frame walls: experimental results on unreinforced walls
}

\author{
Elisa Poletti ${ }^{1}$, Graça Vasconcelos \\ ISISE, Department of Civil Engineering, University of Minho, Campus de Azurém, 4800-058 \\ Guimarães, Portugal \\ Corresponding author: Elisa Poletti \\ Email: elisapoletti@gmail.com
}

\begin{abstract}
Timber frame buildings are well known as an efficient seismic resistant structure and they are used worldwide. Moreover, they have been specifically adopted in codes and regulations during the XVIII and XIX centuries in the Mediterranean area. These structures generally consist of exterior masonry walls with timber elements embedded which tie the walls together and internal walls which have a timber frame with masonry infill and act as shear walls.
\end{abstract}

In order to preserve these structures which characterize many cities in the world it is important to better understand their behaviour under seismic actions. Furthermore, historic technologies could be used even in modern constructions to build seismic resistant buildings using more natural materials with lesser costs.

Generally, different types of infill could be applied to timber frame walls depending on the country, among which brick masonry, rubble masonry, hay and mud. The focus of this paper is to study the seismic behaviour of the walls considering different types of infill, specifically: masonry infill, lath and plaster and timber frame with no infill.

Static cyclic tests have been performed on unreinforced timber frame walls in order to study their seismic capacity in terms of strength, stiffness, ductility and energy dissipation. The tests showed

\footnotetext{
${ }^{1}$ Current address: Nottingham Centre for Geomechanics, Department of Civil Engineering, The University of Nottingham, University Park, Nottingham, NG9 2ED, UK
} 
how in the unreinforced condition, the infill is able to guarantee a greater stiffness, ductility and ultimate capacity of the wall.

Keywords: timber frame, cyclic test, infill, stiffness, energy dissipation, damping

\section{Introduction}

In the past centuries, all sort of natural materials have been used to build walls, such as mud, earth, straw, clay, cork and wood. Various examples can be found through the centuries. Timber has often been associated to masonry as a complementary material to bind masonry. Timber frame walls combine these natural materials, creating a traditional structural element relatively cheap and which can be built with the materials available; the infill can vary from regular masonry to mud and straw. Various types of timber can be used: pine, chestnut or bamboo canes.

Timber frame walls are often adopted in seismic regions as shear walls, in order to resist to horizontal seismic actions. The particular geometry of the walls, with St. Andrew's crosses, is able to dissipate the energy generated by the earthquake motion and the timber structure that acts as a skeleton of the building does not encounter severe damages during the earthquake (Mascarenhas 2004; Gülhan and Güney 2000).

Several onsite investigations after the occurrence of recent earthquakes gave proof of the good seismic resistance of such structures (Gülhan and Güney 2000; Langenbach 2009). Nevertheless, their popularity is not only due to their seismic performance, but also to their low cost and the strength they offer. In fact, this constructive system has been also used for centuries in regions of low seismicity.

The origin of timber frame structures probably goes back to the Roman Empire, as in archaeological sites half-timber houses were found and were referred to as Opus Craticium by Vitruvius (Langenbach 2007). But examples were also found in previous cultures, for example in the Minoan palaces in Knossos and Crete (Tsakanika-Theohari 2006), where timber elements were used according to historians to reinforce masonry (Tampone 1996). Timber frame constructions later spread not only throughout Europe, such as Portugal (edifícios pombalinos), 
Italy (casa baraccata), Germany (fachwerk), Greece, France (colombages or pan de bois), Scandinavia, United Kingdom (half-timber), Spain (entramados) etc., but also in India (dhajidewari), Turkey (himis and bagdadi), Peru (quincha), USA (balloon frame in Chicago), Haiti (Gingerbread houses) (Langenbach 2007; Cóias 2007). In each country different geometries were used, but the common idea is that the timber frame can resist to tension, contrary to masonry, thus providing a better resistance to horizontal loads and moreover providing a sort of confinement to the masonry structure.

In central Europe the aspect of timber frame buildings is very similar, consisting of a frame of horizontal and vertical elements with some sparse diagonal elements. The timber frame constituted the vertical load bearing system (Bostenaru 2004; Götz et al. 1993) as well as the lateral one. Europe still has many examples of historic timber frame buildings (see Fig. 1a), but this construction technique is still used today not only in several European countries, such as France, Spain, Scandinavia and Germany (Fig. 1b), but also in Peru or USA, where the timber frame tradition imported from Europe evolved into modern timber frame houses.

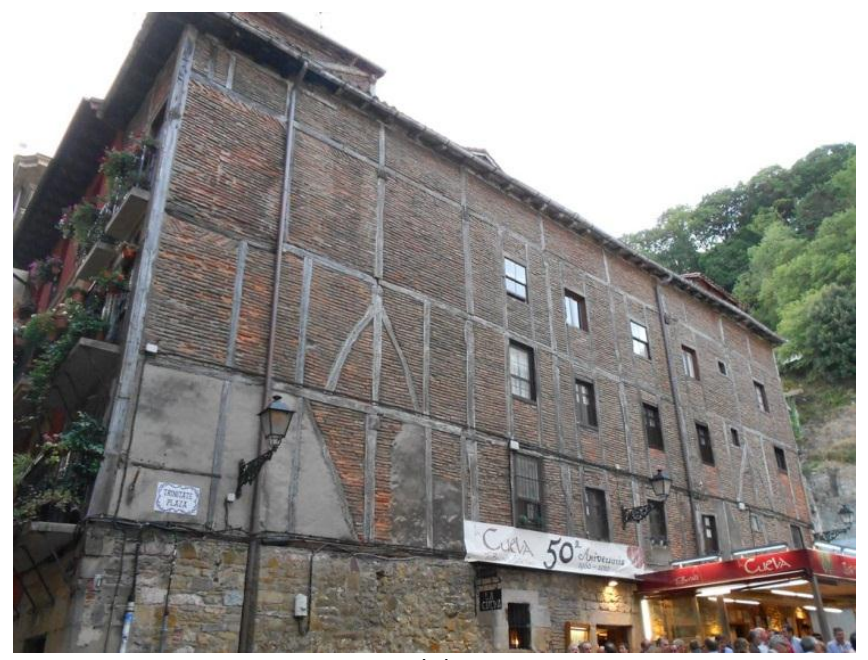

(a)

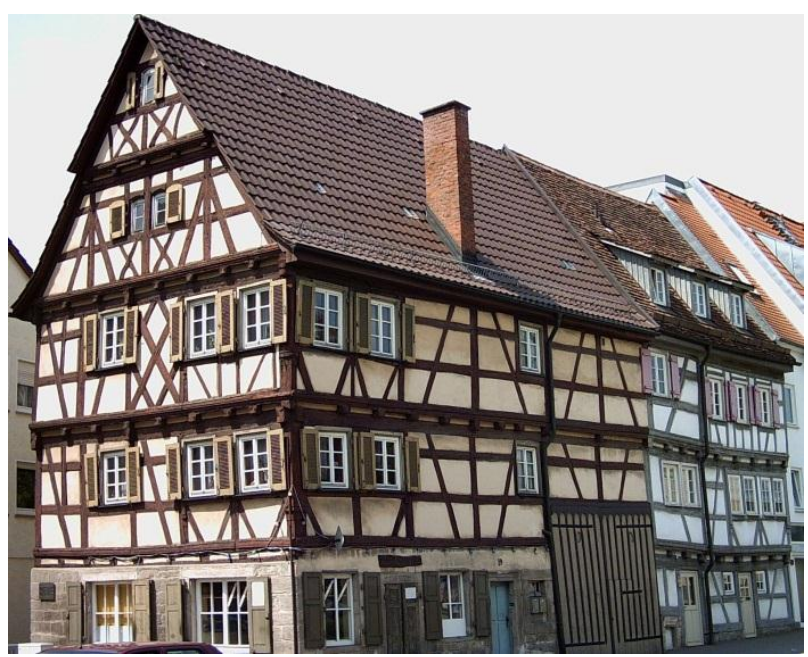

(b)

Fig. 1 Examples of timber frame buildings: (a) historic buildings in calle 31 de Agosto, San Sebastián, Spain; (b) typical timber frame buildings in Sindelfinge, Baden-Württemberg, Germany

A slightly different construction system was adopted in Portugal after the devastating earthquake that hit Lisbon in 1755 for the construction of residential and commercial buildings, known as Pombalino Buildings. The new buildings took their name from the prime minister of the time, the Marquis of Pombal, who encouraged the reconstruction of the city. A Pombalino building is characterized by external masonry walls and an internal timber structure, named gaiola (cage), 
which is a three-dimensional braced timber structure. The gaiola consists of horizontal and vertical elements and diagonal bracing members, forming the typical $X$ of St. Andrew's crosses (Fig. 2a). The internal walls of the gaiola (frontal walls) may have different geometries in terms of cell dimensions and number of elements, as it depended greatly on the available space and the manufacturer's customs. The timber elements are notched together or connected by nails or metal ties. Traditional connections used for the timber elements varied significantly in the buildings: the most common ones were mortise and tenon, half-lap and dovetail connections.

Variability exists in the sectional dimensions of the elements themselves: the diagonal members are usually smaller $(10 \times 10 \mathrm{~cm}$ or $10 \times 8 \mathrm{~cm})$, whilst the vertical studs and horizontal members are bigger (usually $12 \times 10,12 \times 15 \mathrm{~cm}$ and $14 \times 10 \mathrm{~cm}$ or $15 \times 13,10 \times 13$ and $10 \times 10 \mathrm{~cm}$ respectively). The thickness of the walls can vary from 15 to $20 \mathrm{~cm}$ (Mascarenhas 2004; Cóias 2007). The frontal walls act like shear walls in the building. Other internal walls are purely partition walls (costanerias or tabiques) and are made of wooden panels. The buildings may have up to 5 storeys. The ground floor is comprised of stone masonry columns supporting stone arches and clay brickwork vaults and above the first floor develops the gaiola.

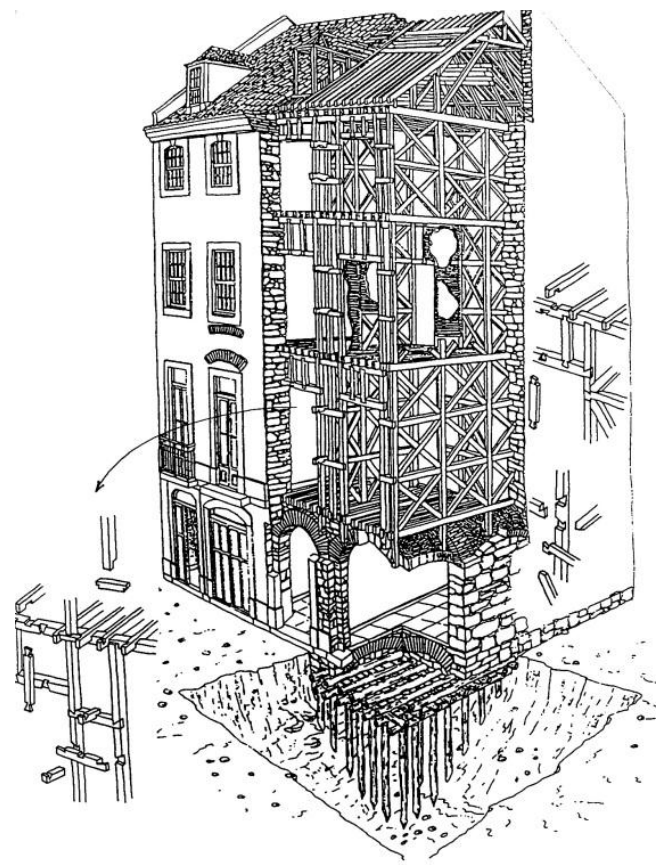

(a)

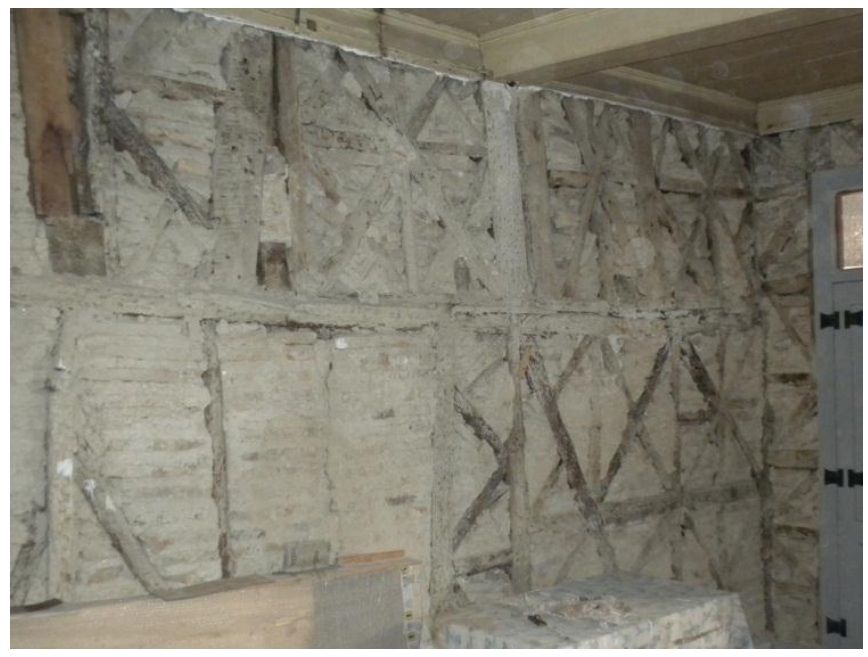

(b)

Fig. 2 Timber frame structures in Portugal: (a) typical Pombalino construction (Mascarenhas 2004); (b) timber frame building in Guimarães

The peculiarity of this type of buildings is that under a seismic event, it is admissible for the heavy masonry of the façades to fall down, as well as for the tiles of the roof and the plaster of the inner 
walls, but the timber skeleton should remain intact, keeping the building standing. It has to be considered that in Pombalino buildings a minimal timber skeleton was present also in the external masonry walls to facilitate and improve the connections with the floors and the inner shear walls (Mascarenhas 2004). This is a construction technology that can improve considerably the out-ofplane behaviour of facades under seismic events.

A hundred years after the earthquake the building practice changed, getting worse from a seismic point of view. Pombalino buildings, where a complete gaiola structure is present and is efficient against seismic actions, were successively replaced by Gaioleiros buildings, where the timber structure does not exist and therefore structurally represent a worse construction quality. According to recent experimental investigations, Gaioleiros buildings present a huge vulnerability under seismic actions (Mendes and Lourenço 2010).

Though this constructive system is typical of the city of Lisbon, timber frame structures can also be found in historic city centres in the north of the country, for example in Porto, Vila Real, Braga and Guimarães (Fig. 2b), even if the seismic hazard is very low in these locations. Their use is attributed to the generalization of the Pombalino construction technology all over the country due its popularity as a lighter and less expensive construction system (Salavessa 2011). In these cities, only the ground floor is comprised of masonry walls, while in all other storeys, each wall is either a frontal wall, even the external ones (called taipa de rodizio), or a wooden partition wall (called taipa de fasquio).

A similar typology was later adopted in Reggio Calabria, Italy (casa baraccata). This version was adopted in the first known seismic code requested from the government (Bianco 2010) after the 1783 earthquake. Another typology specifically adopted for seismic purposes after an earthquake in 1821 is the one that can be encountered in the Greek island of Lefkas, where the timber frame construction is used above the masonry ground floor, but a secondary timber system is inserted inside the masonry of the ground floor to prevent collapse (Vintzileou et al. 2007).

As far as the type of infill is concerned, different materials can be used. Most traditionally, rubble or brick masonry is used as infill material, but other types can be encountered, such as mud and hay 
in the Peruvian quincha, or adobe on willow basketry (Fig. 3a) or wooden planks (Bostenaru 2004) in Germany. These types of walls are lath and plaster walls and are a common in Turkey (bagdadi) and the USA (in balloon frame constructions).

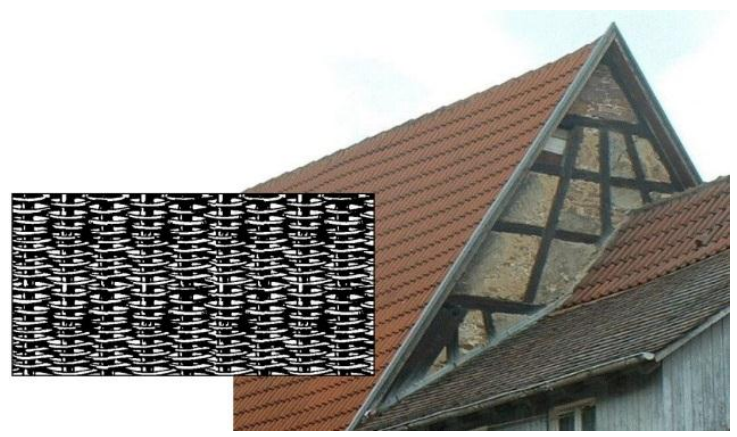

(a)

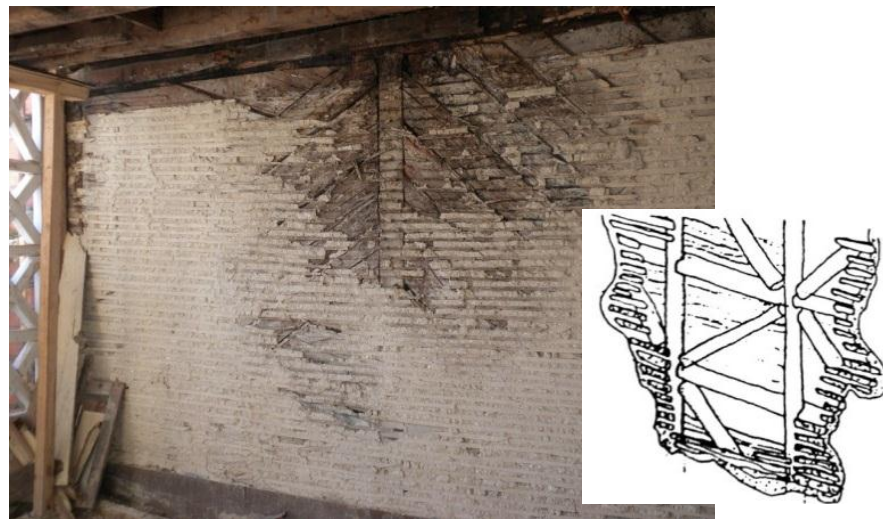

(b)

Fig. 3 Types of infill: (a) willow basketry in Germany (Bostenaru 2004); (b) taipa de fasquio in Guimarães and adoption of same infill for frontal wall (Mascarenhas 2004)

The latter type of infill can also be found in Portugal, where timber frame walls can consist of the timber frame, with or without the diagonals, on top of which the timber strips are nailed directly (see Fig. 3b). Alternatively, wooden boards are nailed on the frame, usually in two layers, one vertical and one diagonal, and subsequently the wood strips are nailed to the boards. The latter example is typically called taipa de fasquio.

\section{Experimental research concerning timber frame construction has known a growing interest} in recent years, as testified by recent and ongoing research that can be encountered.

Various reports are available on the performance of timber frame structures after big recent earthquakes in various countries, but usually the assessment is only qualitative (Gülhan and Güney 2000; Langenbach 2009; Dogangun 2006; Gulkan and Langenbach 2004). The study of this kind of structures under cyclic and dynamic loads to better understand their behaviour when subjected to horizontal loads is mainly still undergoing. Meireles et al. (2012) performed some in-plane cyclic tests on unreinforced timber frame walls and Santos (1997) performed inplane cyclic tests on timber frame walls taken out from an existing building. Kouris and Kappos (2012) performed non-linear numerical analyses on traditional timber frame walls. Some experimental research is available with respect to the evaluation of strengthening techniques on retrofitted timber frame walls with the same typology of the walls mentioned above. Duţu et al. 
(2012) and Gonçalves et al. (2012) performed in-plane cyclic tests and shaking table tests on Pombalino structures. Moreover, Duţu et al. (2013) studied the influence of the diagonal bracing elements. Aktaş et al. (2013) studied the in-plane cyclic performance of traditional Turkish timber frame walls considering different types of infill. Vieux-Champagne et al. (2014) performed tests on Haitian timber frame walls, while Ruggieri and Zinno (2013) performed in-plane cyclic tests on walls typically found in baraccata buildings.

The main aim of this work is to contribute to the state of the art and attain a better insight on the mechanical behaviour of these structural elements under horizontal loads. Indeed, nowadays more and more rehabilitation works have been carried out on historic timber frame structures, often altering significantly the original structure, without any background on the structural behaviour of the original timber framed structures.

The study herein is experimentally based and related the results on an extensive experimental campaign on the seismic behaviour of timber frame walls. For this, and due to the available experimental facilities, quasi-static in-plane cyclic tests on real scale walls were selected.

\section{Experimental campaign performed on timber frame walls}

The objective of this work is to study the seismic performance of traditional timber frame walls, which are shear-resisting walls found in ancient buildings. With this goal in mind, an intensive experimental program was designed based on static cyclic tests on real scale walls, which can simulate, in a simplified manner, the seismic loads expected on a shear wall during an earthquake (Tomaževič et al. 1996).

In Portugal, this kind of study is of great importance, since the majority of buildings in Downtown Lisbon are built with timber frame walls acting as shear walls and many of those buildings are being rehabilitated. However, no real information is available on the behaviour of such structural elements, since neither any earthquakes have hit Lisbon since the devastating one in 1755, nor much experimental researches have been carried out to fill the information gap on this issue. For this reason, a study on the behaviour of such traditional walls is of great importance having in mind 
both the better insight on the seismic behaviour of these structural elements and gather knowledge to better act in rehabilitation purposes.

\subsection{Wall specimens and type of infill}

Different kind of materials could be used both in terms of timber and in terms of masonry, but it was decided to use materials adopted in the Portuguese tradition, i.e. Maritime pine (Pinus Pinaster) and bricks for masonry. It has to be noticed that the bricks used were modern ones, a choice based on cost purposes and on the fact that in rehabilitation works modern materials are usually employed.

The timber frame of the walls was built in a local carpentry specialized in rehabilitation projects by specialized carpenters and masons. Real scale dimensions for the wall specimens were considered. Thus, the sectional dimensions of all the members and the size of the cells were decided according to the dimensions of existing buildings found in literature (Mascarenhas 2004). The top and bottom beams have a cross section of $16 \times 12 \mathrm{~cm}^{2}$ and all the other members of $8 \times 12 \mathrm{~cm}^{2}$. The total width of the wall is $2.42 \mathrm{~m}$ and the total height $2.36 \mathrm{~m}$, resulting in a height to length ratio of approximately 1.0 , even if in some cases this ratio can be higher, whilst the cells are $86 \mathrm{~cm}$ wide and $84 \mathrm{~cm}$ high.

The connections of the main frame are all half-lap connections, as well as the connections between each two diagonals, whereas the connection between the main frame and the diagonals is made by contact (Fig. 4). In all of the connections a nail was inserted. The nails were modern and it has to be pointed out that their length and section is smaller than the ones found in existing buildings. As it should be expected in a manual job, the connections presented some clearances, which can have some influence on the results of the shear tests. Moreover, the timber used was already dry and drying fissures were present in the timber elements, which can, in certain extent, promote the onset of cracking propagation and failure in the walls during testing.

After the completion of the timber frame, eight walls were filled with distinct types of infill to obtain the traditional timber frame walls which characterize many cities in the world. Thus, besides the walls without any infill material, two additional groups of walls with distinct types of infill were considered, namely (1) timber frame walls with brick masonry infill; (2) lath and plaster walls. The 
use of different types of infill aimed also to assess its influence on the cyclic behaviour of masonry walls.

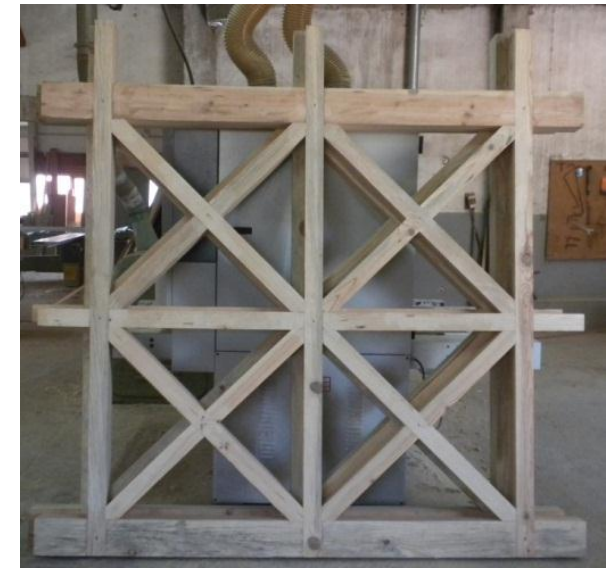

(a)

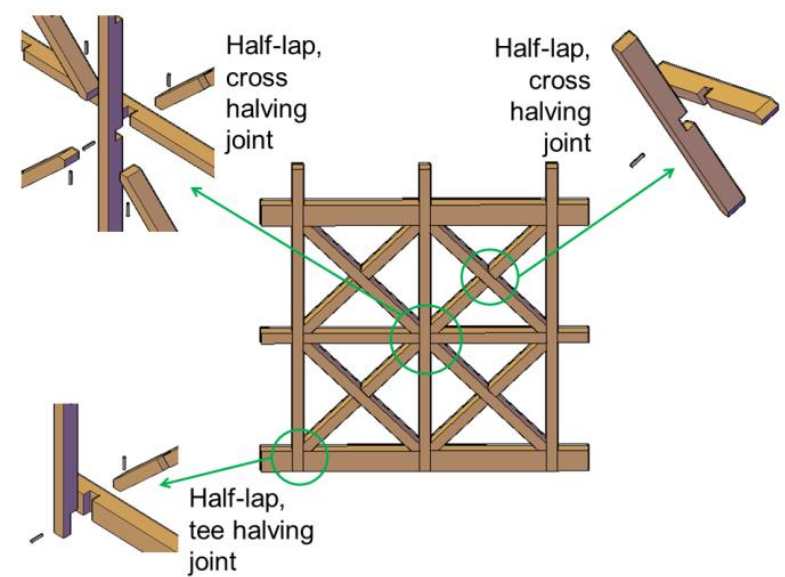

(b)

Fig. 4 Walls construction: (a) Completed timber frame; (b) detail of the type of connections adopted

The first type of infill of the walls was in brick masonry and was carried out in the laboratory by a specialized mason. The masonry pattern was suggested by a Portuguese company from Lisbon which specializes in the rehabilitation of Pombalino buildings. The masonry pattern consists of double leaf masonry with transversal series of bricks every two rows of horizontal double leaf masonry, as detailed in Fig. 5. It was decided to use modern materials available in the market mainly to represent what it is being done nowadays in rehabilitation works, in order to reduce rehabilitation costs. The bricks with modern dimensions $\left(22 \times 6 \times 11 \mathrm{~cm}^{3}\right)$ were cut in half along the thickness (Fig. 5a) and then other cuts were made in order to accomplish with the adopted masonry bond. The masonry pattern adopted and the cut of the modern bricks intended to attain representative masonry existing in historic constructions. Notice that in historic buildings, bricks were usually smaller and moreover, rubble masonry could be used, thus having a more uniform distribution of materials even in the corners. It has to be pointed out that the bricks had a higher strength than those used in the original buildings, so they would confine more the connections.

Additionally, two lath and plaster walls were built, using wood strips with a trapezoidal section (Fig. $5 b)$ spaced of $2 \mathrm{~cm}$. As mentioned above, this type of infill is typical of the north of Portugal, but they can be found even in frontal walls, creating a lighter and more elastic wall (Mascarenhas 2004). The wooden strips have a tendency to confine the wall more, since they link together the posts and the beams, preventing deformations of the walls. 


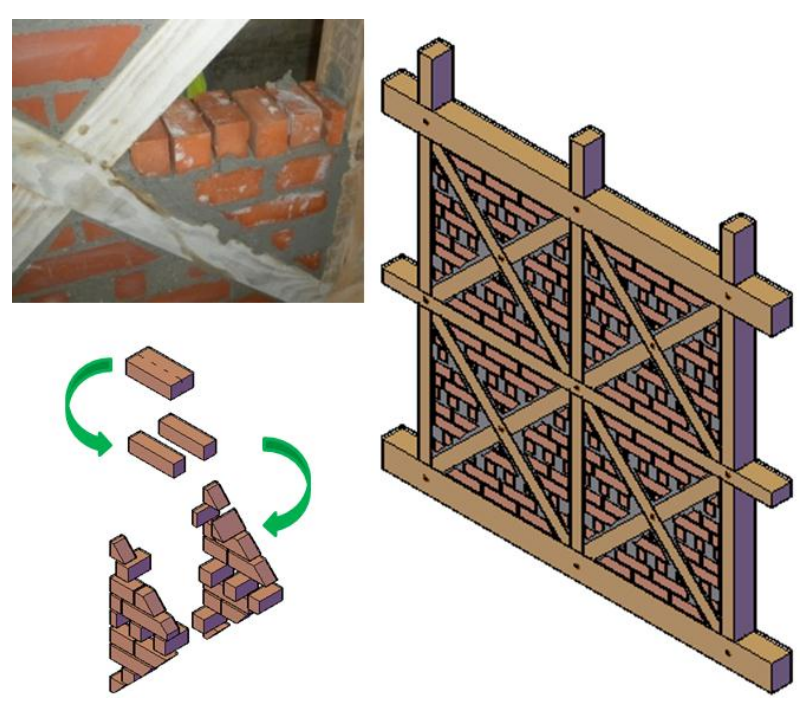

(a)
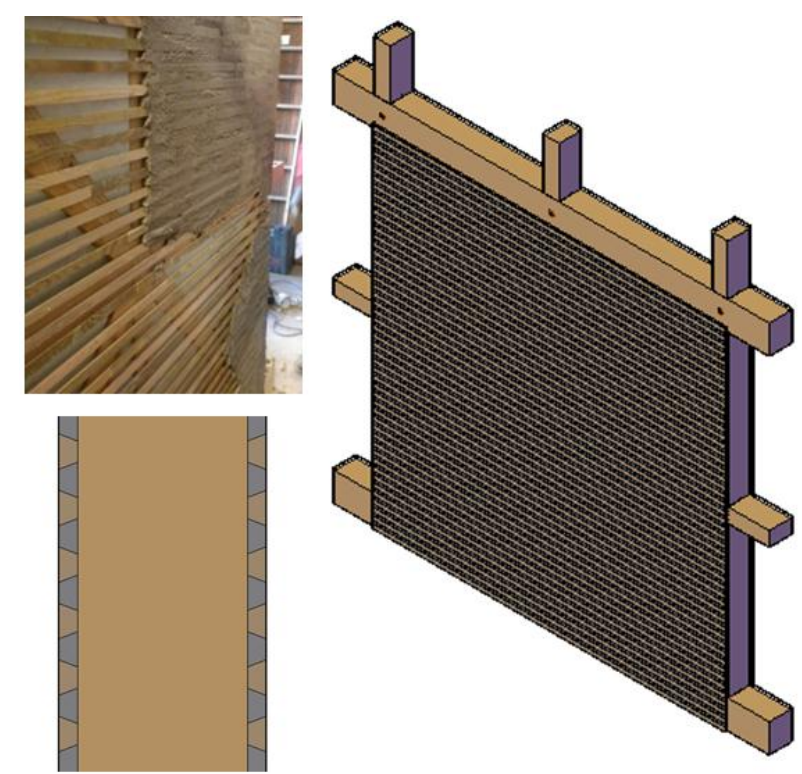

(b)

Fig. 5 Timber frame walls: (a) masonry pattern of infill walls; (b) lath and plaster wall

The wood strips were nailed with a nail gun. The wood strips were not always continuous, but of varying length, and were nailed to each timber element they encountered with at least 3 nails. Mortar was inserted between the strips (the same mortar used to build the masonry infill) and inside the timber frame for a thickness of $1,5 \mathrm{~cm}$ on each side of the wall. To prevent a higher mortar thickness, isolating panels were inserted in the wall to reduce the free space inside, but without providing any additional stiffness or weight to the wall.

\subsection{Material properties}

In order to be able to better assess the behaviour of the walls during the cyclic tests, it is important to have an idea about the strength and mechanical behaviour of the materials, namely wood, mortar and masonry infill.

Wood from timber frame has been characterized in compression and bending according to European Standard EN 408 (2003). Mortar has been characterized both in bending and compression according to European Standard EN 1015-11 (1999), bricks have been tested according to standard EN 772-1 (2000) and masonry has been characterized in compression according to European Standard EN 1052-1 (1999) and in shear according to standard ASTM E519-02 (2003). In Table 1 the average results for all materials tested are presented, with the coefficient of variation (c.o.v.) indicated in brackets. 
The timber adopted (Pinus pinaster) was tested in its structural dimensions, considering a cross section of $16 \times 12 \mathrm{~cm}^{2}$; therefore defects, such as knots and fissures, considerably influenced the results (Poletti 2013). Nevertheless, the coefficient of variation obtained is in accordance to what expected for timber (Dinwoodie 2000). The average results attained in the experimental campaign are comparable with the results obtained in literature from Portuguese Maritime pine (Cruz et al. 1997).

Table 1 Average values of material properties tested

\begin{tabular}{|c|c|c|c|c|c|c|}
\hline \multicolumn{2}{|c|}{ Material } & Wood & $\begin{array}{l}\text { Mortar (lab) } \\
\text { at } 56 \text { days }\end{array}$ & $\begin{array}{c}\text { Mortar } \\
\text { (construction) } \\
\text { at time of wall } \\
\text { test }\end{array}$ & Bricks & Masonry \\
\hline \multicolumn{2}{|c|}{$\begin{array}{c}\text { Compressive strength } \\
{[\mathrm{MPa}]}\end{array}$} & $\begin{array}{c}38.18 \\
{[11.95 \%]} \\
\text { (// to the } \\
\text { grain) }\end{array}$ & $\begin{array}{c}4.90 \\
{[1.88 \%]}\end{array}$ & 3.92 [13.13\%] & $\begin{array}{c}34.5 \\
{[15 \%]}\end{array}$ & $\begin{array}{c}7.53 \\
{[7.31 \%]}\end{array}$ \\
\hline \multicolumn{2}{|c|}{ Bending strength [MPa] } & $\begin{array}{c}47.84 \\
{[28.38 \%]}\end{array}$ & $\begin{array}{c}1.55 \\
{[13.36 \%]}\end{array}$ & 1.55 [9.24\%] & & \\
\hline \multirow[t]{2}{*}{$\begin{array}{c}\text { Modulus of } \\
\text { elasticity } \\
\text { [GPa] }\end{array}$} & $\begin{array}{l}\text { global in } \\
\text { bending } \\
\text { local in } \\
\text { bending }\end{array}$ & $\begin{array}{c}10.82 \\
{[18.02 \%]} \\
12.02 \\
{[18.30 \%]}\end{array}$ & & & & \\
\hline & $\begin{array}{c}\text { in } \\
\text { compression }\end{array}$ & $\begin{array}{c}11.04 \\
{[18.05 \%]}\end{array}$ & & & & $\begin{array}{c}6.74 \\
{[19.13 \%]}\end{array}$ \\
\hline \multicolumn{2}{|c|}{ Shear strength [MPa] } & & & & & $\begin{array}{c}0.20 \\
{[9.17 \%]}\end{array}$ \\
\hline \multicolumn{2}{|c|}{ Shear modulus [GPa] } & & & & & $\begin{array}{c}1.06 \\
{[14.66 \%]}\end{array}$ \\
\hline
\end{tabular}

An important variation has been found even in mortar specimens. The mortar used in the construction of masonry infill was composed of Portland cement $32,5 \mathrm{~N}$, hydrated lime and fine and medium sand. The proportion of the raw materials adopted for the mortar was 1:2:6 in volume. The water/cement ratio was about 1.5 in volume. The mortar specimens tested consisted of a batch prepared in the laboratory and one constituted of specimens gathered during the construction of masonry in the different walls. It is seen that there is a significant difference among the values of both bending and compressive strength among the mortar specimens corresponding to the distinct walls as well as between the specimens prepared in the laboratory and those prepared during construction (Poletti 2013). This variation can be 
attributed to a certain extent to the difficulty to keep constant the water/cement ratio so that an adequate plasticity and workability of the mortar was achieved.

\subsection{Test setup and instrumentation}

The cyclic tests were carried out using the setup illustrated in Fig. 6a. The application of the vertical load was done by means of vertical hydraulic actuators applied directly on the three posts of the walls and connected to the bottom beam through steel rods which connected the actuators to a hinge welded in the bottom beam, so that the actuators were able to follow the horizontal movement of the wall.

The horizontal displacement was applied to the top timber beam through a hydraulic servo-actuator with a maximum capacity in terms of displacement and load of $200 \mathrm{~mm}$ and $250 \mathrm{kN}$ respectively. The actuator was connected by means of a 3-D hinge to the reaction wall and a two-dimensional hinge was connecting it to the wall specimen. The top beam of the wall was confined by two steel plates connected through sufficiently stiff steel rods so that cyclic displacements could be imposed to the top of the wall. The bottom timber beam was connected to the bottom steel profile in 6 points and it was confined laterally in order to prevent any kind of movement in this element.

The out-of-plane displacements, which proved to be a delicate problem for these slender walls, were prevented by a guide created in the upper beam through means of punctual steel rollers distributed along the length on the beam on the two sides of the wall (Fig. 6b). For a detailed description see Poletti (2013).

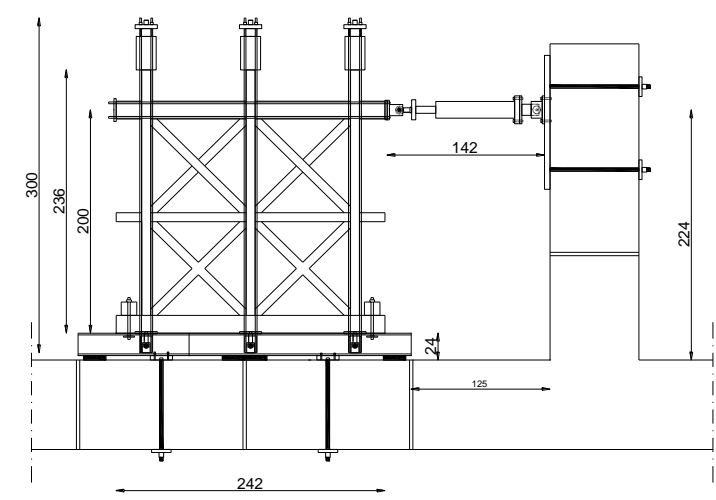

(a)

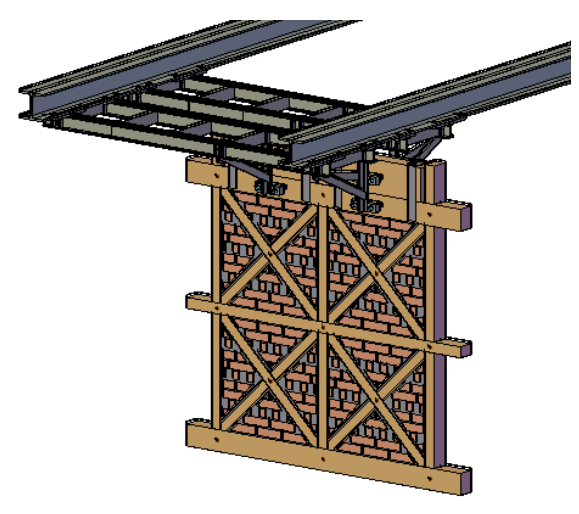

(b)

Fig. 6 Test setup: (a) in-plane setup; (b) out-of-plane setup

All of the walls were instrumented with linear voltage displacement transducers (LVDTs), placed in strategic positions to capture the global and local behaviour of the walls. Fig. 7 illustrates the 
general position of the LVDTs. The horizontal displacements at the top and mid height beam are measured on both sides of the wall. The control displacement is applied to the top beam on the right side of the wall (front view) and LVDT TOP measures the corresponding displacement on the other side of the wall (TOP). Two LVDTs (ML and MR) are placed on the two sides of the walls at mid height and measure the horizontal displacement of the central beam on the two sides. The vertical uplift of the three bottom connections are monitored through LVDTs BR, BM and BL.
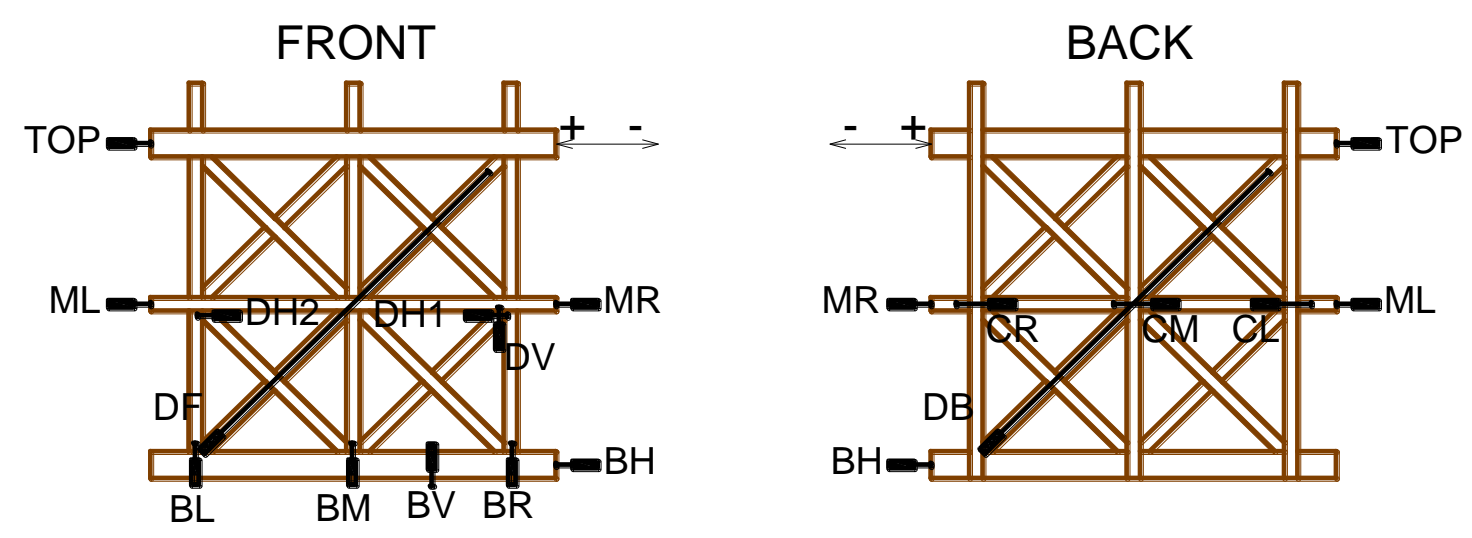

Fig. 7 Instrumentation in walls tested

The displacement in the diagonals is measured with LDVTS DF and DB at the front and back of the wall, measuring the displacements of the different diagonals in order to appreciate the effect of the compressive and tensile cycles as well as differences on the two sides of the wall.

The local opening of the half-lap and nailed connections in different positions of the walls was measured through LVDTs CR, CM, CL, DH1, DH2 and DV. In order to ascertain that the bottom beam is completely fixed during the test, LVDTs BV and BH measured the vertical and horizontal detachment from the bottom profile and the lateral confinement respectively.

\subsection{Vertical loading and cyclic procedure}

Two different pre-compression load levels were considered, namely $25 \mathrm{kN} /$ post and $50 \mathrm{kN} /$ post. The application of different vertical load levels aimed at assessing the influence of this variable on the lateral response, considering also that it is possible that due the fact that timber frame buildings have known a great rehabilitation effort in the last years, their structure and use have been changed, being feasible that additional vertical loads can act on this type of walls. Notice that originally these walls are intended to act mainly as shear walls. Therefore, it is convenient to study 
the effect of additional loads on the structural element. The calculation of the amount of vertical load to be applied was made according to Eurocode 1 (2002) considering a live load of $2 \mathrm{kN} / \mathrm{m}^{2}$, $0.7 \mathrm{kN} / \mathrm{m}^{2}$ for the timber floors, $0.17 \mathrm{kN} / \mathrm{m}^{2}$ for the partition walls, $3.11 \mathrm{kN} / \mathrm{m}$ as the weight of the timber frame walls with an influence area of $3.5 \mathrm{~m}$. The partial safety coefficients were considered to be equal to 1.0 as we are in the sight of an experimental campaign. A total vertical load of $75 \mathrm{kN}$ was thus obtained. It should be pointed out that the weight of the timber roof was attributed to the external masonry walls, as this was the original configurations of Pombalino buildings. In order to consider changes in the structures and a redistribution of loads, taking into account the possibility that timber frame walls could bear more than just the weight of the timber floors, the amount of vertical load applied was doubled and its influence was studied during the cyclic tests.

The cyclic procedure adopted during the tests was based on standard ISO 21581 (2010). In order to better capture the highly non-linear behaviour of the walls, additional steps were added in the procedure, considering an increment in the applied displacement of 10\% (see Fig. 8).

The displacements applied were derived from a previous monotonic test performed on the wall in order to evaluate its displacement capacity (Poletti 2013). From the displacement of $10 \%$ of the maximum load and higher, each loading step was repeated three times. After the initial cycle, two stabilization cycles were introduced. In this way, the reduction in strength and stiffness can stabilize before increasing the applied displacement in the next loading step. Stabilization cycles allow the wall to achieve the maximum damage for a given displacement. For further details, see Poletti (2013).

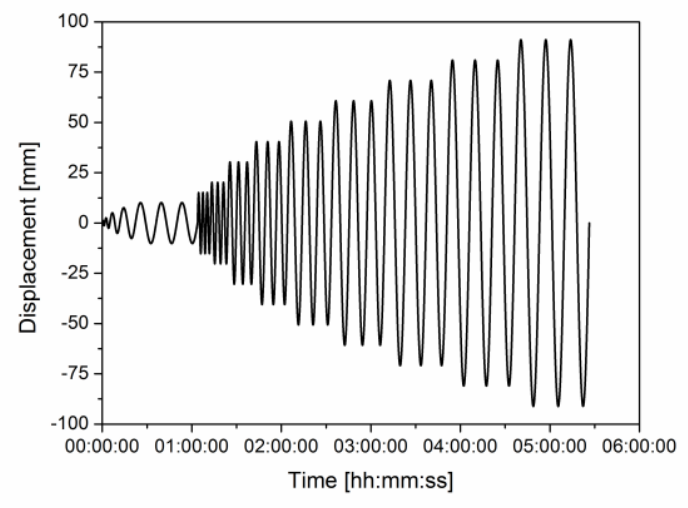

Fig. 8 Test procedure used in the experimental campaign of timber shear walls 
In total, ten unreinforced timber walls were tested, distributed for three distinct groups, see Table 2, according to the type of infill: (1) unreinforced infill walls (UIW), filled with brick masonry; (2) unreinforced fasquio walls (UFW), i.e. lath and plaster walls; (3) unreinforced timber walls (UTW) without infill. The number 25 or 50 used in each designation is associated to the vertical load applied in each post of the walls, $25 \mathrm{kN}$ and $50 \mathrm{kN}$ respectively. The number of specimens for each typology is indicated inside brackets (Table 2).

In all tests, bolts were used in the protruding part of the central beam in order to prevent the local failure and ensure the continuity of the central beam, as it would be found in an existing building.

Table 2 Typology of the specimens tested under cyclic loading

\begin{tabular}{cccccc} 
Specimen & \multicolumn{2}{c}{ Vertical load } & & Type of infill \\
Lath and plaster & No infill \\
\hline \hline UIW25 (3) & 25kN/post & 50kN/post & Brick masonry & & \\
\hline UIW50 (3) & $\checkmark$ & & $\checkmark$ & $\checkmark$ & \\
\hline UFW25 (1) & $\checkmark$ & $\checkmark$ & $\checkmark$ & $\checkmark$ & \\
\hline UFW50 (1) & & $\checkmark$ & & \\
\hline UTW25 (1) & $\checkmark$ & & & $\checkmark$ \\
\hline UTW50 (1) & & $\checkmark$ & & & \\
\hline \hline
\end{tabular}

\section{Analysis of test results}

As aforementioned, the static cyclic tests can simulate in a simple way the seismic loading and provide important information on the overall mechanical behaviour and shear resistance of walls subjected to lateral loads. Cyclic test results performed on timber frame walls with and without infill are here presented and a discussion of their general behaviour is reported. The presentation and discussion of the results can be divided into three parts, namely: (1) discussion of the typical forcedisplacements hysteresis diagrams; (2) discussion of the main deformation features and typical failure modes; (3) assessment of seismic performance indicators.

\subsection{Typical hysteretic diagrams}

All unreinforced timber frame walls with masonry infill subjected to the same vertical precompression level present a similar behaviour. Walls UIW25, tested with the lower vertical precompression load, present a predominant rocking behaviour (see Fig. 9a), characterized by the Sshape of the force-displacement diagrams (Magenes and Calvi 1997), with a significant vertical 
uplift of the posts. In Fig. 9, complementary to the hysteresis diagrams, the evolution of the vertical displacements measured by LVDTs, placed in the posts at the base of the walls, with the top lateral displacement of the walls is also shown. It is seen that the lateral posts were uplifting as much as $50 \mathrm{~mm}$, pointing out the important rotation experienced by the walls.

It should be noticed that the low vertical level applied in the wall, in conjunction with the aspect ratio of the walls (approximately 1), contributes in great extent to the predominant flexural rocking mechanism. Besides, the geometry of the connections at the base of the walls is also important for the promotion of this resisting mechanism. In fact, the half-lap connection at the base of the wall reveals to be the more vulnerable to tensile forces, given that only one nail was added and, additionally, in this part of the walls, the connection has no continuity, contrarily to the other connection of the posts. Notice that this trend for the uplift of the wall with the detachment of the post at the base is also seen in case of other typologies of cantilever shear walls, namely masonry walls, with the opening of horizontal cracks (Magenes and Calvi 1997).

Once the connections were completely open, the walls exhibited a low decrease in terms of strength, since the bottom connections were not working anymore. This behaviour is typical of the rocking mechanism, for which high displacements can be reached with little reduction of strength (Magenes and Calvi 1997).

The hysteretic curves are quite flat at the origin, when there is the load inversion, which is associated to the pinching effect. The local crushing of wood when dowel-type fasteners are used, in this case nails, corresponding to the attainment of the embedment strength of wood, results in the degradation of the connection in successive cycles. This clearance, promoted by the crushing of wood, results in the sliding at the connection before the contact between wood and the fastener is achieved again (Piazza et al. 2005), so that the connection is again effective, leading to the gain of resistance.

The behaviour of the walls was not symmetrical in the first cycles, becoming then more symmetrical as the displacement in the walls increased, which can be attributed to some imperfection on the connections. Generally, higher loads were reached in the positive direction, 
while the ultimate displacement was slightly higher in the negative one. This load asymmetry can be related to the asymmetry in the lateral load application, as only one horizontal actuator is used.

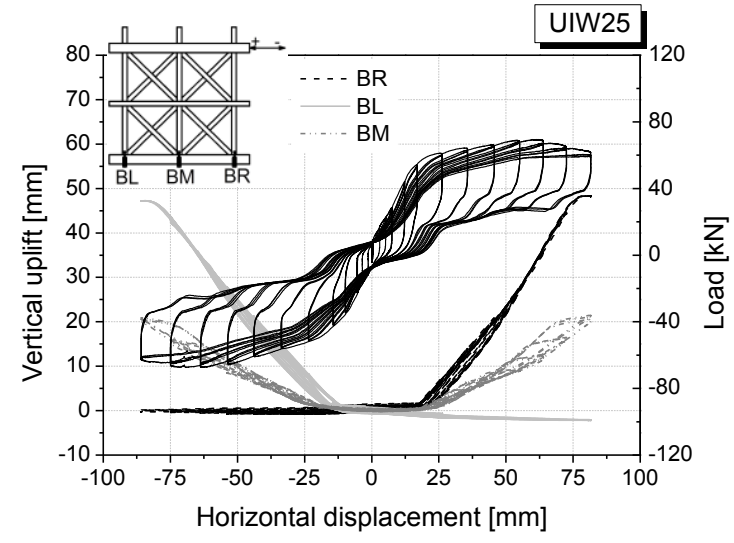

(a)

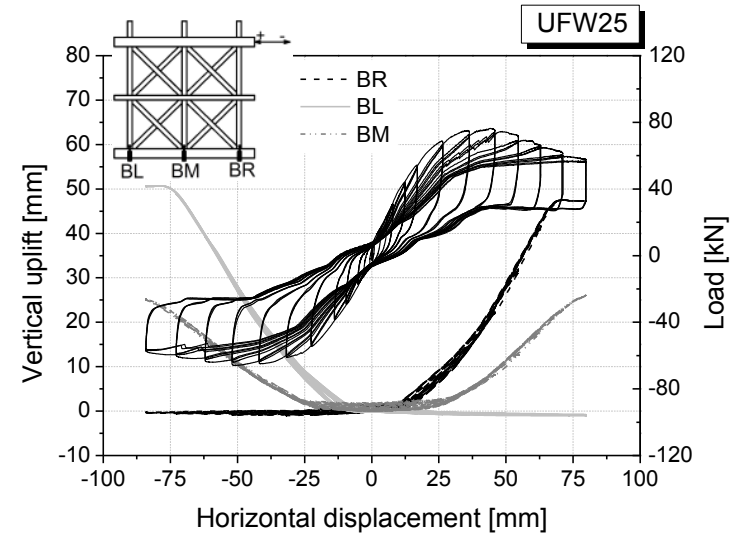

(c)

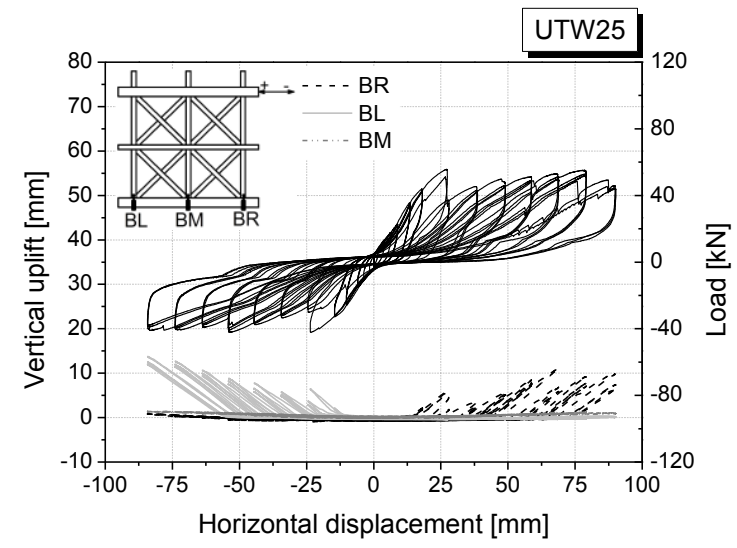

(e)

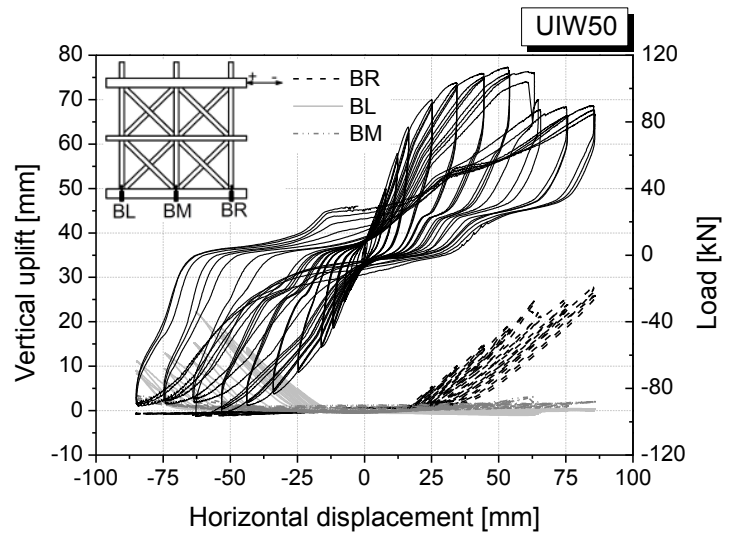

(b)

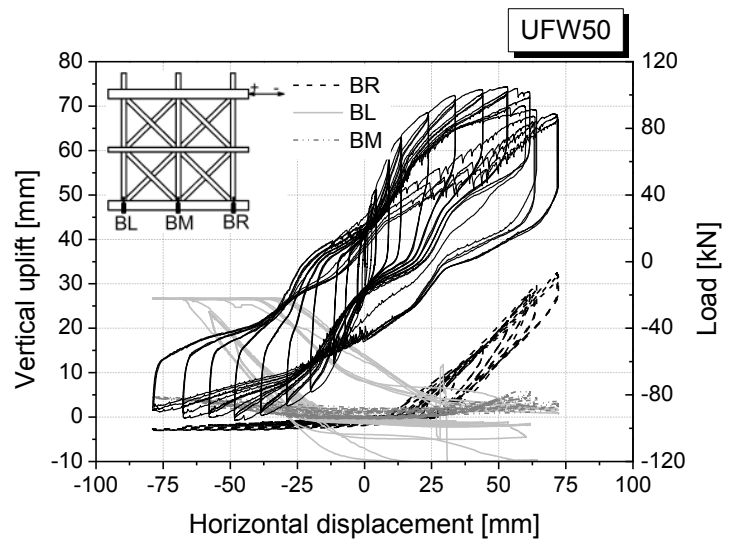

(d)

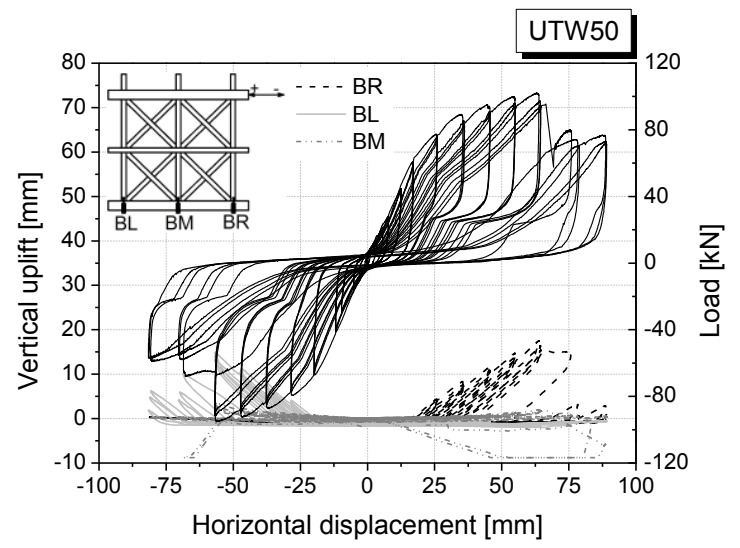

(f)

Fig. 9 Hysteretic curves for the different timber frame walls: (a) brick masonry infill - lower vertical load level; (b) brick masonry infill -higher vertical load level; (c) fatchwork infill - lower vertical load level; (d) fatchwork infill - lower vertical load level; (e) timber frame wall - lower vertical load level; (f) timber frame walls - higher vertical load level

The rocking mechanism was evident even in walls submitted to the higher level of vertical precompression load (walls UIW50), even if in this case a shear component was clearly present (Fig. 9b). The uplift of the vertical posts occurred during these tests too, in a lower amount, but it still 
conditioned the shape of the hysteretic loops. The walls exhibit a progressive loss of stiffness, even though the ultimate load does not differ greatly from the maximum one.

It should be mentioned that the boundary conditions can have an important effect on the shape of the force-displacement diagrams, particularly in the unloading regime of the response. In effect, the timber walls are tested as cantilever. Besides, it is seen that the vertical posts can detach from the bottom beam, which appear to reproduce the real condition existing and observed on site.

Indeed, if the form of the hysteretic loops is compared with the uplift of the vertical posts for the same horizontal displacement, one can notice that: (1) the change in stiffness in the loading branch starts when the lateral posts start uplifting; (2) the plateaux that occur in the unloading branch of each cycle occur when the bottom connections start closing, which was observed even during different experimental tests (Gonçalves et al. 2012). The hysteretic loops found present a peculiar form which is not present, for example, in similar tests conducted on historic timber frame walls (Meireles et al. 2012; Santos 1997). The test results found in Santos (1997), related to similar traditional walls taken from existing structures, point out clearly distinct features of the unloading branch of the force-displacement diagrams. In this case however, the base of the wall was concreted into a concrete slab, and thus completely fixed at the base, avoiding the possibility of detaching the posts from a bottom wood beam.

The hysteresis diagrams found for lath and plaster walls for both vertical load levels are very similar to those observed for timber frame walls with masonry infill, see Fig. 9c,d. Wall UFW25, tested under the lower vertical load level, exhibited a clear flexural behaviour, characterized by an even more remarkable S-shaped diagram (see Fig. 9c). In case of wall UFW50, tested with the higher vertical load level, a mixed flexural/shear behaviour characterizes the response, similarly to what was observed for the walls tested with brick masonry infill. The confining effect given by the timber strips assured an important lateral stiffness, limited the working of the central connections leading thus to the damage concentration at the base of the posts. The behaviour was confirmed by the vertical uplift of the posts. The uplift was higher for the wall tested with the lower vertical load, with a vertical uplift reaching up to $50 \mathrm{~mm}$. The walls UFW50 reached a vertical uplift of $32.43 \mathrm{~mm}$, still significant (Fig. 9d). Also in this case, it is possible to notice in the unloading branch 
of the hysteretic loop there is a plateau for decreasing displacements, which is attributed to the closing of connection at the base of the posts.

The higher asymmetry in the cyclic response, namely at the level of the maximum lateral strength observed in lath and plaster walls can be attributed to the asymmetry on the damage patterns of these walls. The asymmetry is more relevant in case of the walls submitted to the higher level of vertical pre-compression. Moreover, these walls, due to the higher stiffness they reached, experienced some out-of-plane movement, noticeable for the lower displacement capacity attained by the wall UFW50.

Timber frame walls with no infill exhibited a different behaviour in relation to the filled timber frame walls. The shear resisting mechanism predominated in the lateral response over the minor flexural component. But, as it can be noticed from the hysteretic diagrams (Fig. 9e,f), the walls experienced severe pinching. This appears to indicate that the pinching can in a certain extent be avoided by the infill, both brick masonry and lath and plaster. Moreover, the unloading branch of the various loops is more regular, even if the plateau characterizing the post uplifting is still present.

For both vertical load levels, the vertical uplift of the posts was similar and minimal, if compared to that of filled walls (13.8mm for UTW25 and $17.51 \mathrm{~mm}$ for UTW50). Contrarily to what happened in filled walls, the uplift was higher for the wall tested with the higher vertical load level, but this was due to the fact that the wall failed for higher levels of horizontal displacement and the posts were more stressed. UTW25 exhibited an early failure and after that the posts were stressed less, thus uplifting less.

For wall UTW25 (Fig. 9e), once the wall failed (at an applied displacement of $30.36 \mathrm{~mm}$ ), it was possible to observe an accommodation of the wall, which recuperated strength, even though stiffness degraded, managing to reach almost its maximum load. This resulted from a stress redistribution; after the central connection failed, stresses were redistributed to other connections, allowing the wall to regain strength. The same did not happen to the wall with the higher vertical load, as failure occurred for higher values of displacement (applied displacement of $70.85 \mathrm{~mm}$ ) and it was not able to recover some strength. 
As it can be deduced from the analysis done until now, the presence of infill greatly changes the response of timber frame walls to cyclic actions. The type of infill, though, does not appear to overly influence their behaviour.

The amount of vertical pre-compression applied to the walls greatly influences their behaviour. It changes its response to cyclic actions, since a higher pre-compression leads to a stiffening of the wall and to a greater load capacity. Timber frame walls with brick masonry infill gained $64.7 \%$ in terms of maximum load, while only losing $2.8 \%$ in terms of ultimate displacement. Lath and plaster walls gained $29 \%$ in terms of maximum load, but their ultimate displacement decreased of $2.8 \%$. In case of timber frame walls an increase of vertical pre-compression resulted in an increase on the lateral resistance of $104.6 \%$, with a loss in terms of ultimate displacement of only $2.7 \%$.

\subsection{Deformational features of the walls}

Besides the uplift of the post analysed previously, some other deformational features are also here analysed in order to better understand the lateral behaviour of the different walls. Notice that the bottom beam did not uplift from the steel profile on which the wall was anchored. Moreover, horizontal displacement of the bottom beam was controlled and found out to be less than $0,5 \mathrm{~mm}$.

The behaviour of the diagonals was similar in all three UIW25 walls. The main diagonals were opening and closing according to the forces acting along the diagonal being in tension or compression. The movement was generally higher when the element was in tension, which should be associated to the possibility that the contact connections between the diagonal and main frame are able to detach. If one element failed, the diagonals would experience greater displacements, since the opening of the connections would allow a higher movement to the diagonals. In general, the displacement of the diagonals in UIW25 walls was of $10 \mathrm{~mm}$ when in compression and $18 \mathrm{~mm}$ when in tension.

The displacement along the diagonals was higher for UIW50 walls (Fig. 10a). This result is in correspondence with the more evident shear behaviour of the walls for this vertical precompression. For all walls, the diagonals reached a displacement of about $30 \mathrm{~mm}$.

It is observed that the displacement in the diagonal of walls UTW are clearly higher than the ones recorded in the filled walls. The maximum displacement measured in the UTW walls subjected 
$50 \mathrm{kN} /$ post is $20 \mathrm{~mm}$ higher than in case of walls UIW submitted to the same level of precompression, see Fig. 10b. This behaviour revealed the much more relevant shear resisting mechanism exhibited by UTW walls. Indeed, the failure for both UTW walls occurred when the central beam failed in shear, due to the high shear concentration induced by the diagonals. In fact, since the masonry infill was not present to stiffen the walls, the diagonals were able to move freely, inducing greater damages in the walls. In both walls, the main diagonal reached a deformation of approximately $50 \mathrm{~mm}$ both in the positive and in the negative direction once the central beam failed, which caused the increase in the rate of displacement of the diagonals. In Fig. 10b it is clearly visible how, once the central beam failed in shear, the diagonals started opening with a higher rate. For filled walls, the higher movement experienced by the diagonals as well as a non-linear deformation of the vertical posts is also more relevant in case of walls submitted to higher levels of vertical load. The lower uplift allows the shear deformation to be more significant, thus elongating the diagonals. When the uplift of the walls is high, the vertical post detaches from the bottom beam and the rocking mechanism predominates, resulting in lower deformation in the diagonal. In this case, the diagonals rotate together with the wall in a more rigid way.

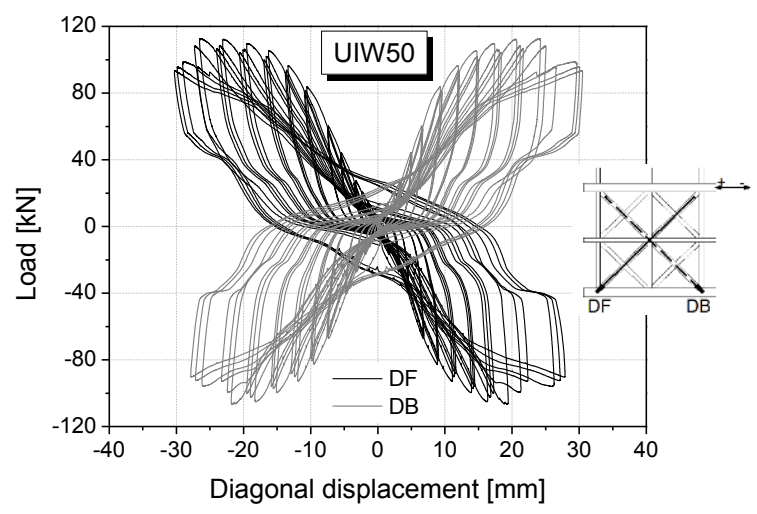

(a)

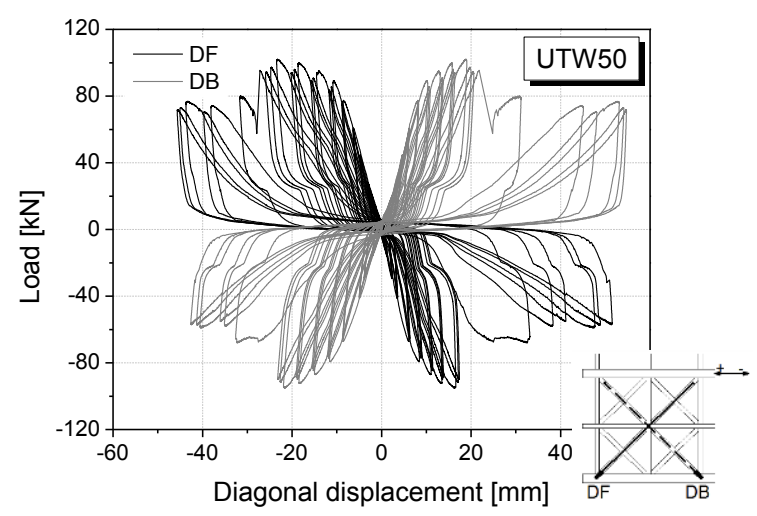

(b)

Fig. 10 Diagonal openings: (a) walls UIW (pre-compression - 50kN/post); (b) walls UTW (pre-compression - 50kN/post) For filled walls, when the global horizontal displacement at mid height of the walls submitted to the lowest level of vertical pre-compression is compared to the top displacement of the walls, it is seen that it is approximately half of the top displacement (Fig. 11a). This explains why the posts did not experience significant bending and justify the rocking deformation of the wall. Besides, the displacement measured on the right and left sides of the walls are approximately the same, which 
confirms also the absence of local relative deformations at the connections and thus the predominant rigid deformation of the walls. In UIW50 walls, the horizontal displacement reached in the central beam is higher than half of the horizontal displacement reached at the top of the wall (54.3mm vs. $84.29 \mathrm{~mm}$ for wall UIW6, for example), which means that the lateral displacement has an additional component beyond the component associated to the rotation of the wall and that corresponds to the shear component of deformation. In case of UTW walls, where the shear deformation predominated, the lateral displacement at mid height of the walls in the right and left sides of the walls measured by the LVDTs MR and ML respectively are completely different when a certain loading direction is considered. Once the central connection failed in shear, the increase on the lateral deformation of the walls led to the increase of the crack opening and thus to the remarkable elongation of the diagonals. This effect is measure by LVDTs MR and ML when the wall is pulled or pushed respectively. When the wall is pushed, the displacement measured by LVTD MR is low as it is in the part of the wall not affected by the shear crack opening of the central connection. The same behaviour is recorded in the LVDT ML when the walls is pulled, confirming the symmetry of deformations under positive and negative directions of the lateral load. With the crack opening at the central connection it is not possible to have a full displacement transfer between border posts.

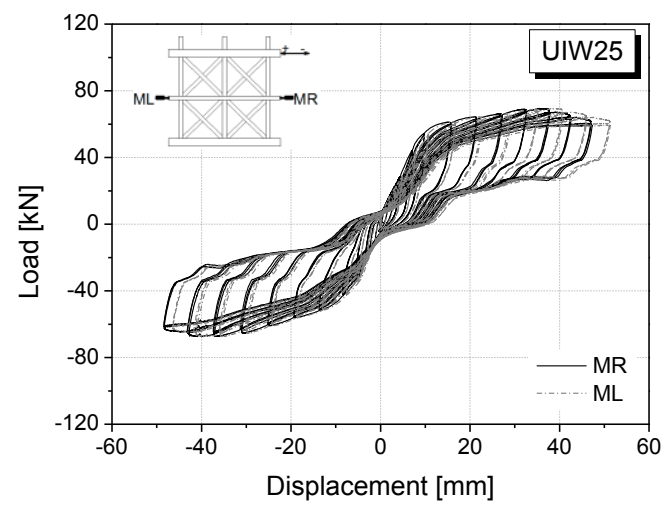

(a)

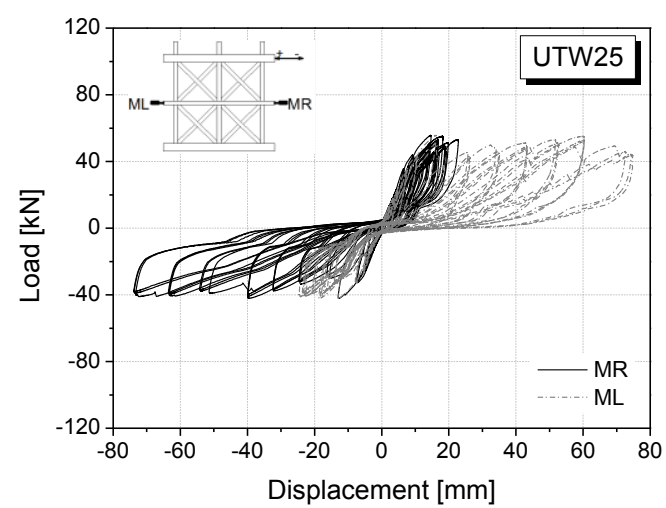

(b)

Fig. 11 Displacement at mid height of the wall: (a) UIW25 wall - lower vertical load level (25kN/post); (b) UTW25 wall lower vertical load level (25kN/post)

Notice that crack opening at the central connection increases considerably as the lateral displacement increases, see Fig. 12, causing the differential opening on the two sides of the wall. It 
is clear that, after failure, the connection was opening progressively, until it was not possible anymore to register its opening, due to reaching the end of the linear range of the transducers.

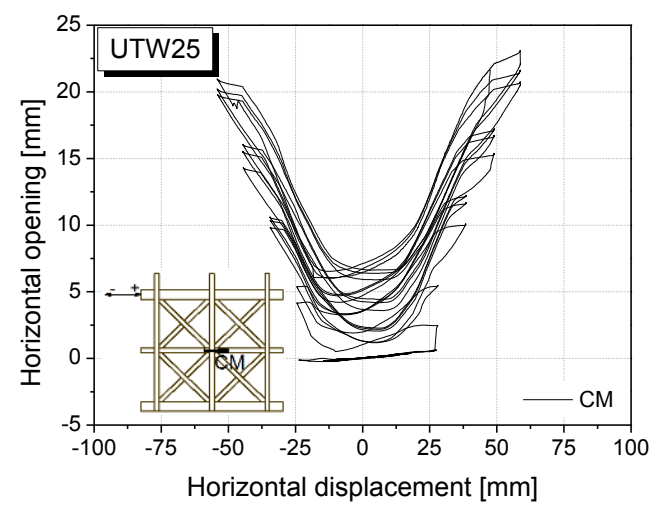

Fig. 12 Opening of the half-lap connections at central mid height for unfilled timber walls - intermediated half-lap connection $\mathrm{CM}$

The movement of the diagonals could also be observed in the single connections, where the nailed connections between the diagonals and the main frame were opening various millimetres during the test. From Fig. 13a,b, where the horizontal component of the displacement (DH1 and DH2) of the diagonal bars are displayed for the infill and unfilled timber frame walls, it is seen that the diagonals were detaching in one direction, while in the other direction they were cutting the connections. This means that the posts separate from the diagonals when tensile forces are applied along the diagonals. The separation is increasing continuously in the case of infill timber frame walls, while for timber frame walls there is a significant increase in the detachment near failure. In the case of lath and plaster walls (not pictured), the wooden strips, connecting the diagonals to the main frame, contribute to the limitation of the separation between the diagonal and the main frame due to the lateral confining effect. A similar opening was observed even in the vertical direction, reaching openings of $9 \mathrm{~mm}$ for displacement values of $80 \mathrm{~mm}$. It has to be pointed out that in case of filled walls diagonals exhibited equal uplifting of the vertical posts, given that both masonry blocks and wooden were preventing an independent behaviour of the two elements. In case of unfilled timber framed walls, the diagonal elements can move independently. This is also an indication of the fact that the strong flexural behaviour of infill walls was mainly associated to the presence of the infill material. In fact, in timber frame walls without infill, the movement of the 
diagonals reached values of $30 \mathrm{~mm}$ for displacement values of $80 \mathrm{~mm}$, measured manually during the tests due to lack of transducers in those connections.

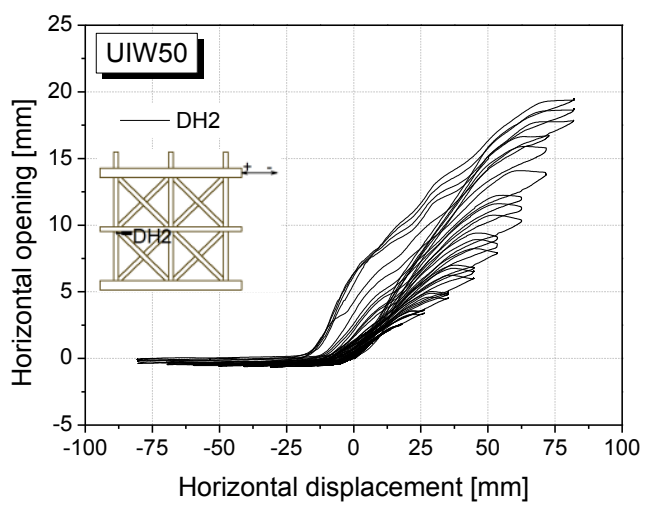

(a)

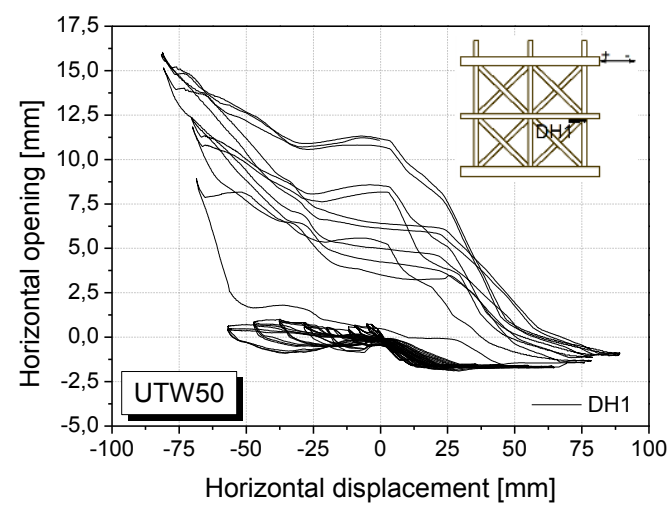

(b)

Fig. 13 Opening of nailed connections for walls tested with higher vertical load: (a) horizontal opening of diagonal nailed connection in timber frame wall with masonry infill; (b) horizontal opening of diagonal nailed connection in timber wall with no infill

The distinct infill material influences also the horizontal opening of the half-lap connections at mid height of the distinct walls at the border posts, see Fig. 14. It is observed that the half-lap connections between central beam and external posts are higher in case of UIW walls, when compared to UFW walls. This difference is associated to the limitation of relative displacements imposed by the application of wooden strips. In fact, this type of infill ties together the whole wall, limiting the in-plane opening of the connections. On the other hand, in the walls UTW the opening of the half-lap connections was limited up until failure, after which the connections were opening freely (Fig. 14c).

It should be noticed that the vertical pre-compression also influences the maximum opening of these connections. To sum up, it can be concluded that in general, for filled walls tested with the lower vertical load level, the opening of connections was small and not very significant, the walls were rotating as a whole, thus allowing little possibility to local deformations. On the other hand, filled walls tested with the higher vertical load level experienced important deformations in the connections, with openings in both half-lap and nailed connections. Timber walls instead experienced, for both vertical load levels, important deformations in all connections, since the absence of infill guaranteed a prevalent shear component and free deformation capacity to the walls. 


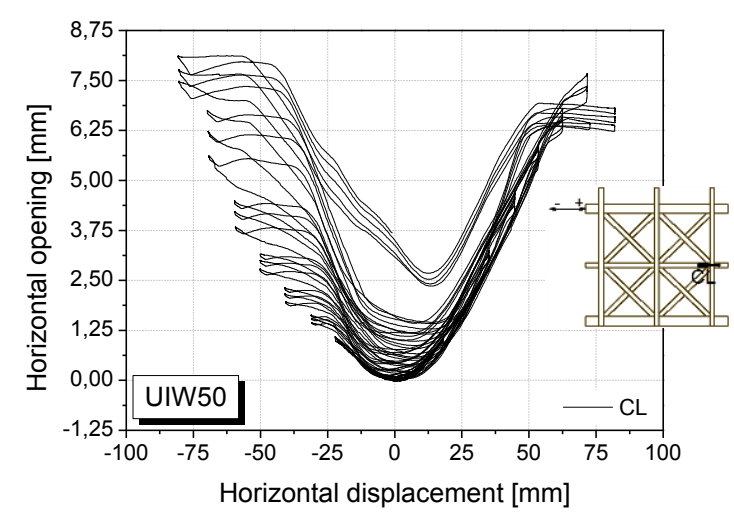

(a)

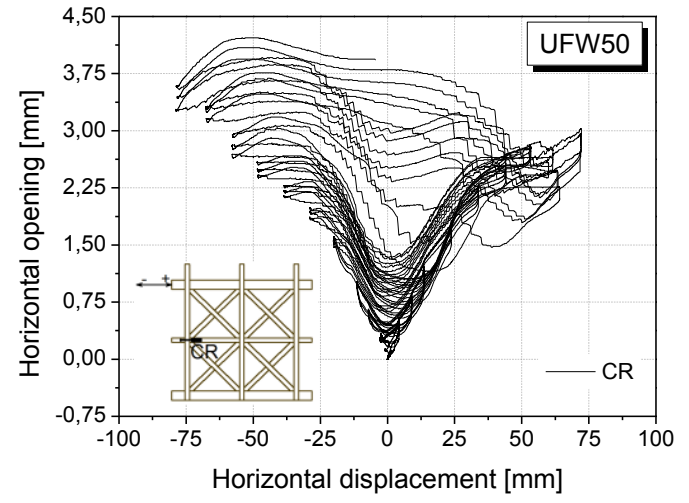

(b)

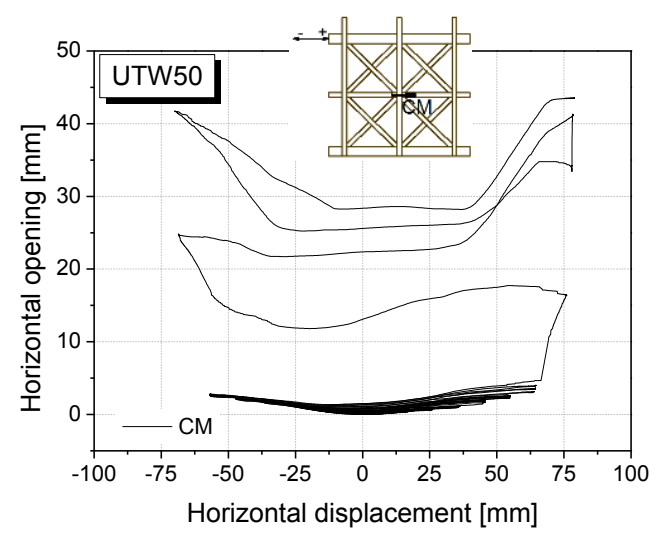

(c)

Fig. 14 Opening of the half-lap connections at mid height of the walls; (a) timber frame walls with masonry infill (UIW) half-lap left connection CL; (b) lath and plaster walls (UFW) - half-lap right connection CR; (c) unfilled timber walls (UTW) - intermediated half-lap connection CM

\subsection{Typical damage patterns}

The distinct deformational features of the walls discussed previously resulted from distinct damage patters exhibited by the different walls. The typology of walls is particularly relevant in the damage patterns when filled and unfilled timber frame walls are compared.

The predominant resisting mechanism exhibited by infill timber frame walls was rocking, particularly in case of the lower vertical pre-compression load level, see Fig. 15a. As mentioned above, when a wall rocks, it can achieve large displacements without a significant loss in strength and thus with low damage. In the case of the infill walls here analysed, the damages found were not great and thus it was generally simple to reassemble the walls for retrofitting.

In case of brick masonry timber frame walls, the detaching of brick masonry from the timber frame was evident due to the rocking movement. As the confinement of the frame was loosening during the test, masonry tended to move out-of-plane, moving out as much as $2 \mathrm{~cm}$. The vertical posts and 
the diagonals were clearly uplifting and the nail placed in the half-lap connections offered little resistance to the tearing force provided by the post.

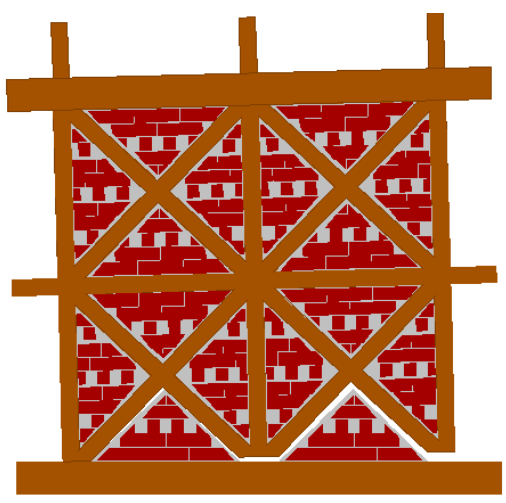

(a)

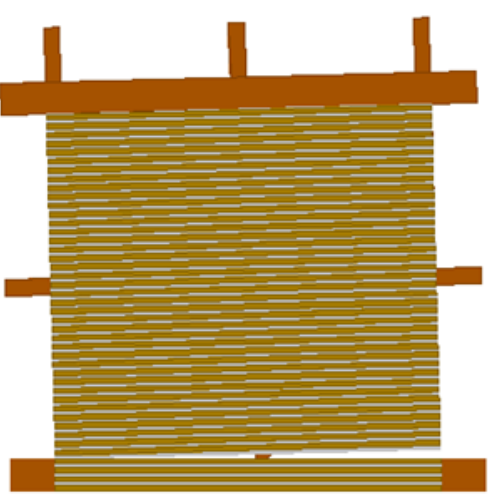

(b)

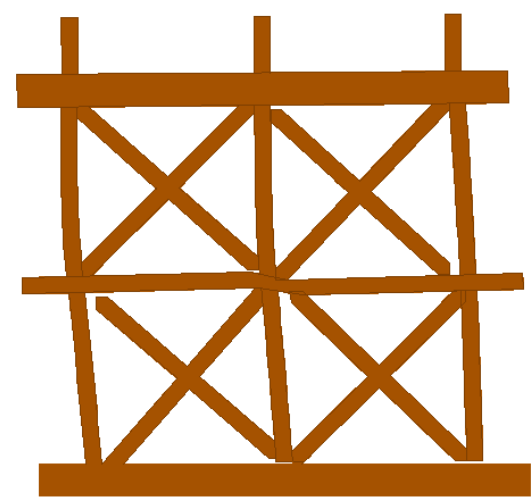

(c)

Fig. 15 Behaviour of the wall during the test: rocking of walls for lower vertical load level: (a) timber frame wall with masonry infill; (b) lath and plaster wall; (c) timber frame wall

During the tests, the bottom connections presented a tendency to open out-of-plane, so that the post would come out, as the plastic deformation of the nail would impede the post to re-enter in its original position during unloading. The movement only involved the lower connections. Moreover, the cyclic movement of the walls contributes for the trend of pulling-out of the nails from the connections. After the test, the nails at the bottom connections were severely deformed as the result of the pulling effect of the posts in correspondence to the half-thickness of the half-lap connection. The damages at the connections were more relevant in UIW50 walls, both in terms of masonry cracking and damages to the timber frame. In particular, crushing of the central half-lap connection was observed, a loosening of the half-lap connections at mid height, with probable damage to the connections from the nail pulling out of the diagonals. Fig. 16a,b shows the typical crack pattern at the end of the test in brick masonry timber frame walls. Notice that for masonry infill walls, most of the damage is concentrated in the lower part of the wall. In general, masonry was not greatly damaged, even if most of the cracks were developing at the unit-mortar interfaces for walls submitted to the highest pre-compression level and only some bricks fell out mainly due to nails pulling out from the diagonals and causing the damages to masonry. Besides, the interface between masonry and timber was very weak, leading to the early detachment of the masonry from the main framed as mentioned above. Masonry tended to behave as a block, while the wall was rocking, the triangles filling the frame were moving accordingly. When the wall was uplifting 
significantly, the masonry in the lower part of the wall would "fall down" and it did not offer additional stiffness to that part of the cell.

In lath and plaster walls the damages on timber connections were similar to the ones observed in masonry infill walls. The walls exhibited rocking mechanism, particularly for the lower level of precompression, see Fig. 15b, and the damages were higher for the higher vertical load. It was clearly visible that no timber strips broke but bent where the post was uplifting. Besides, in UFW50 wall, the left post failed at the base, due to the stress concentration associated to rocking, inducing also crushing of the bottom beam. This led also to remarkable out-of-plane deformation due to the lack of support. The damages in the mortar were more noticeable in the lower part of the wall for the lower vertical load level (Fig. 16c), as happened for masonry infill walls. For the higher vertical load, the cracking density was higher, developing both at the timber elements borders, as in the wall submitted to the lowest pre-compression, and in the triangle cells, see Fig. 16d.

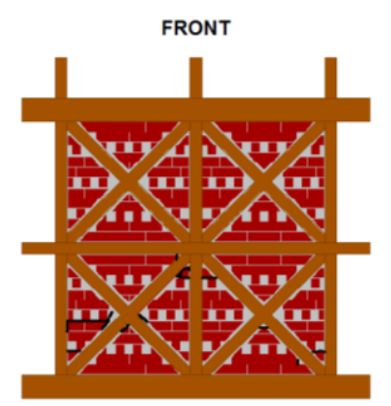

(a)

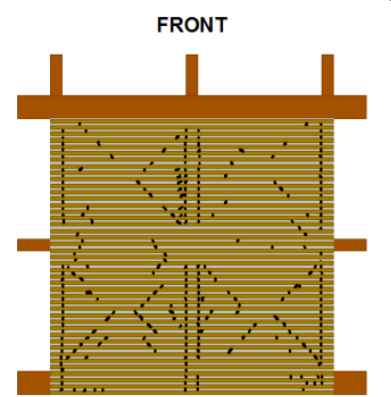

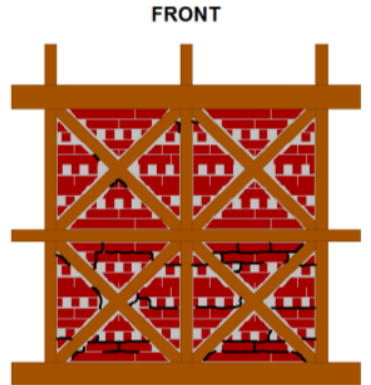

FRONT

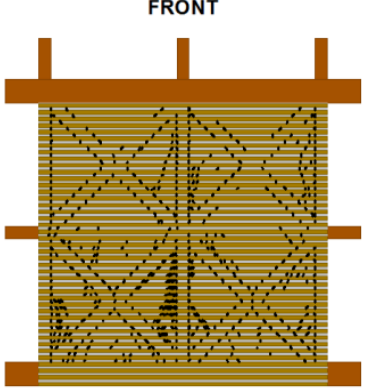

(b)
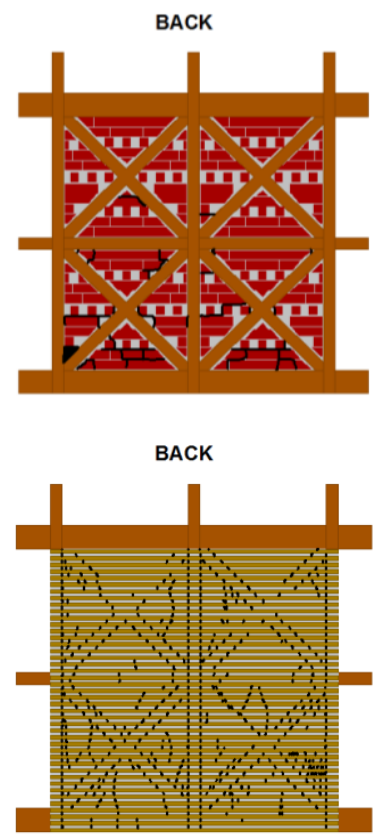

(d)

(c)

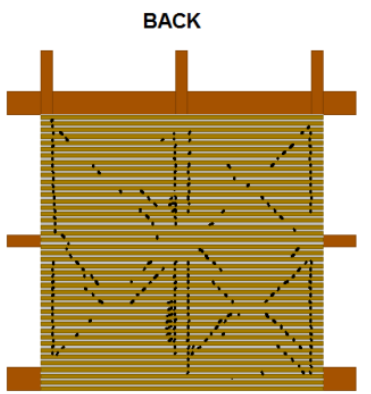

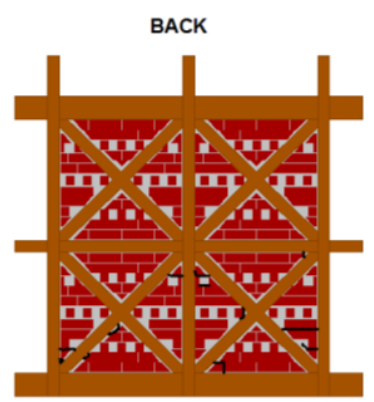

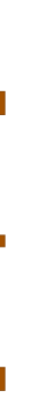

Fig. 16 Typical crack patterns in infill walls: (a) masonry infill lower load; (b) masonry infill higher load; (c) lath and plaster wall lower load; (d) lath and plaster wall higher load

As already mentioned, timber frame walls without infill presented a much more relevant shear deformation, which resulted also in damage patterns characteristic of the predominant shear behaviour for both pre-compression load levels considered, see Fig. 15c. Thus, contrarily to what happened in infill walls, the damages in timber frame walls were concentrated at the central beam, namely at the central connection, where diagonal elements converged. 
In fact, since the diagonals were able to move freely due to the absence of the infill, and the posts experienced minimum uplifting, the shear stresses induced by the diagonals in the central beam were higher and in both cases the central connection in the beam crushed due to the lateral compression applied by the diagonals. Even the lateral connections experienced higher stresses and in case of wall UTW25 the right connection failed, due to the major shear action of the diagonals and to the stresses redistribution which occurred after the early failure of the central connection. According to what was mentioned in the previous section, the cracking at the central connection promoted the elongation of the diagonal leading to the separation between the diagonals and the main frame, see Fig. 15c, with openings easily visible. The walls subjected to the higher pre-compression load experienced more severe damage than the walls under the lower load. The failure of the walls occurred when the central connection of the central beam began crushing (Fig. 17a). Even if some strength degradation occurred, the ultimate displacements are comparable to those of the walls tested under the lower pre-compression.

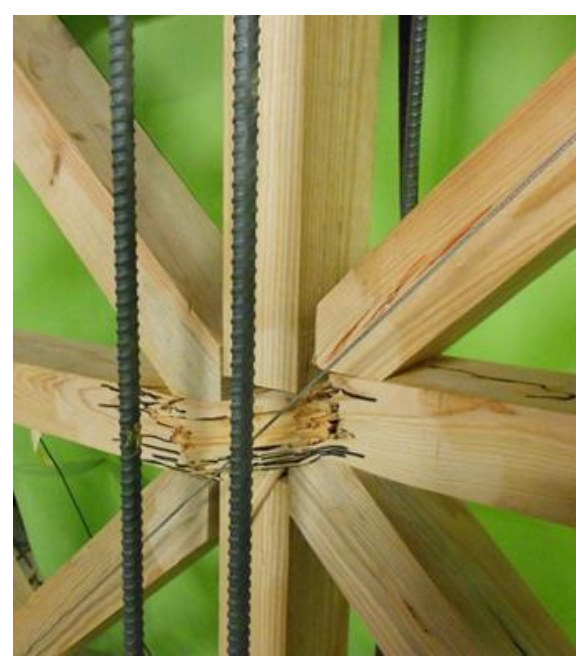

(a)

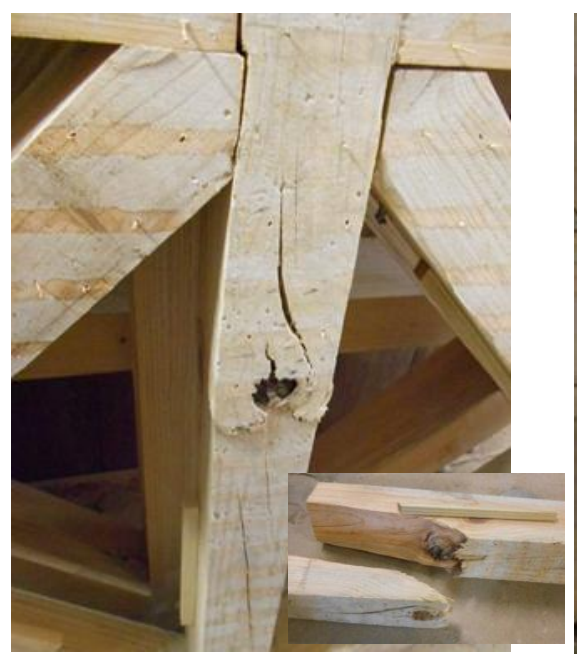

(b)

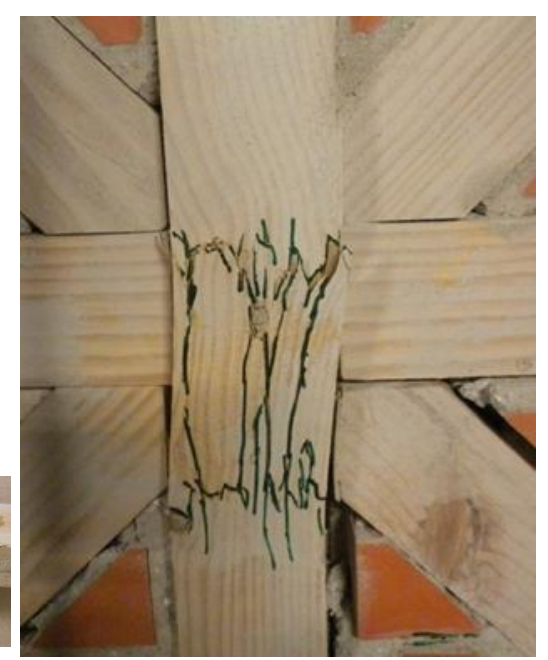

(c)

Fig. 17 Damages in central connection: (a) timber frame walls; (b) lath and plaster walls; (c) timber frame walls with masonry infill

The differences in terms of damage the central half-lap connection according to the distinct types of walls can be seen by comparing the damage patterns shown in Fig. 17, obtained for the highest level of pre-compression. In both filled walls, some deformation of the central connection was observed but it was not enough to result in severe damage as in the timber walls. In case of lath and plaster walls (Fig. 17b), the central middle connection did not crush, because the damage was moved to a weak point in the central post, i.e. a knot from which cracking propagated causing the 
failure of the central post. For infill walls (Fig. 17c), the crushing of the central connection was concentrated on the post, and not on the beam as for timber frame walls. The confining effect given by the infill guaranteed that the connection did not open at the same levels of those of timber walls. Moreover, the damage and relative opening were more progressive.

\subsection{Seismic performance}

In the seismic design of new timber structures or in the rehabilitation of existing structures, including historic timber frame walls, the study of the seismic performance is of paramount importance. Since the seismic response of timber structures is very complex and time dependant, a better understating of the hysteretic factors that govern the problem is important for a safe and economical seismic design or for the adoption of the most adequate retrofitting measures. Parameters such as ductility, energy dissipation, overall cyclic stiffness, equivalent viscous damping ratio and lateral drifts characterize the behaviour of timber shear walls and are helpful in evaluating the performance of a structure under cyclic loading. In this section, the main seismic parameters are presented for the walls previously analysed.

\subsubsection{Obtaining the bi-linear idealized diagrams}

Aiming at obtaining the equivalent bilinear diagrams, which are a perfectly elasto-plastic representation of the actual response of the wall specimens, the monotonic envelopes for each wall tested were defined, see Fig. 18a. The average monotonic curves for each wall typology are also presented in Fig. 18b. The monotonic envelope curves are defined as the curve connecting the points of maximum load in the hysteresis plot in each displacement level (ISO 215812010 ). According to the standard, the envelope curves should be plotted for both the initial cycle and the two stabilization ones, but, since low variations were observed during the tests among the three repetitions, the envelope curves of the two stabilization cycles were discarded.

All walls present a softening behaviour, but the strength degradation is not much remarkable. Only two walls, namely UFW25 and UTW50, had a loss in strength higher than $20 \%$.

It is seen that in average the type of infill material has some influence on the initial stiffness and maximum lateral resistance but it depends mainly on the vertical pre-compression level. In case of 
low levels of pre-compression load (25kN/post), the maximum resistance is higher in case of lath and plaster walls, whereas the initial stiffness has no change. In walls with higher level of precompression, the maximum load is approximately the same and the initial stiffness is higher for lath and plaster walls. In case of timber walls with no infill, it is seen that they present both lower initial stiffness and lower lateral strength for both load levels, even if the differences are less marked for the higher load. This difference on the lateral resistance for the lower level of pre-compression should be attributed to the clear difference on the resisting mechanism that predominates for each typology. In fact, timber frame walls with infill submitted to the lower level of pre-compression present a predominant rocking behaviour, contrarily to the timber frame wall without infill, which behaves predominantly in shear. When the vertical load applied increases to $50 \mathrm{kN} /$ post, the infill timber frame walls present some rocking but it is clear that a shear component of deformation is present, which is closer to the shear behaviour of the timber frame walls with no infill.

All timber frame walls present similar results for each load level. The variation in terms of lateral resistance was of $7 \%$ for walls submitted to $25 \mathrm{kN} /$ post, while it was of $5 \%$ for walls submitted to $50 \mathrm{kN} /$ post. In terms of ultimate displacement, the variation was even lower: $0.99 \%$ in the positive direction and $2.34 \%$ in the negative one for walls submitted to $25 \mathrm{kN} /$ post and $2.11 \%$ in the positive direction and $2.92 \%$ in the negative direction for walls submitted to $50 \mathrm{kN} /$ post (Poletti 2013).

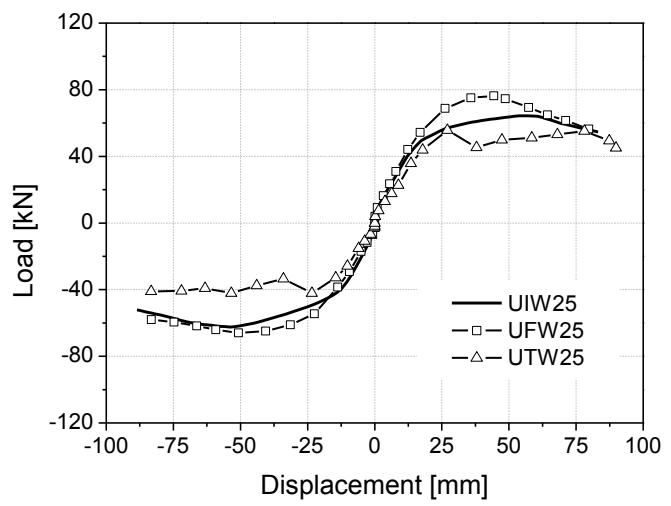

(a)

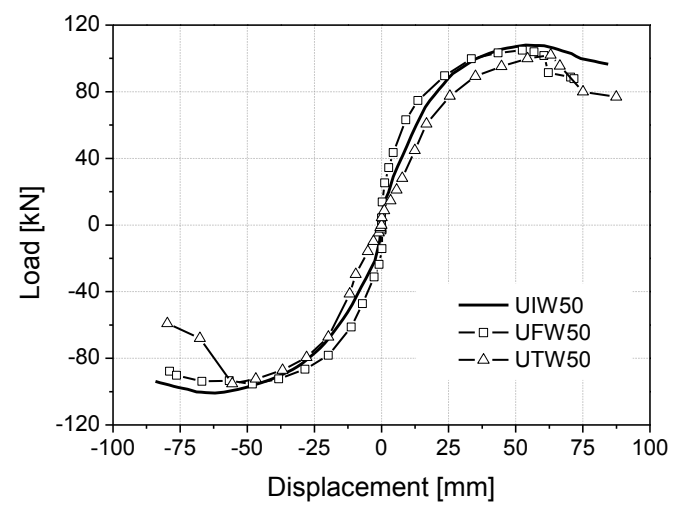

(b)

Fig. 18 Envelope curves of tested walls, mean values: (a) lower vertical load level; (b) higher vertical load level

In order to obtain the bi-linear diagram, the yield displacement was defined according to the approach proposed by Tomaževič (1999), i.e. considering the failure load as $80 \%$ of the maximum load and calculate the yield displacement from the equivalence of the areas (Fig. 19a). It 
should be pointed out that for the majority of the walls, the ultimate displacement corresponds to the maximum one obtained experimentally, since only two walls lost more than $20 \%$ of the maximum load in the degradation process. Therefore, the ultimate displacement corresponds to the displacement reached in the last cycle imposed to the walls.

Fig. 19b presents the bilinear curves used to obtain the values of ductility for all walls. Only positive values are shown, since it was decided to take the positive displacements of the envelope for the calculation of seismic parameters.

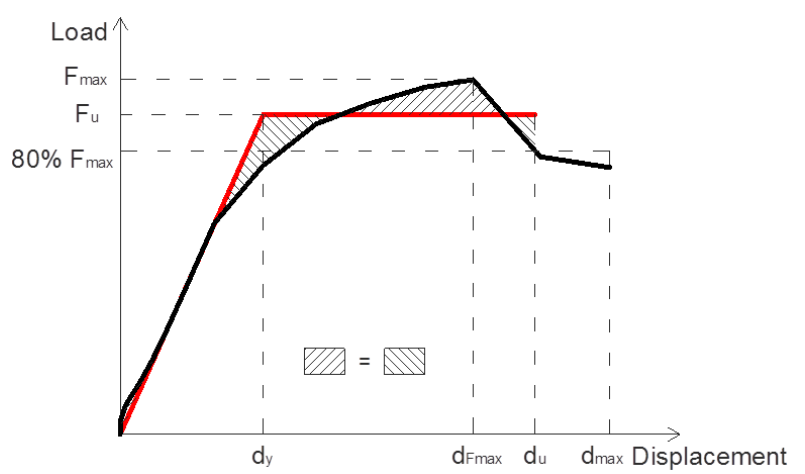

(a)

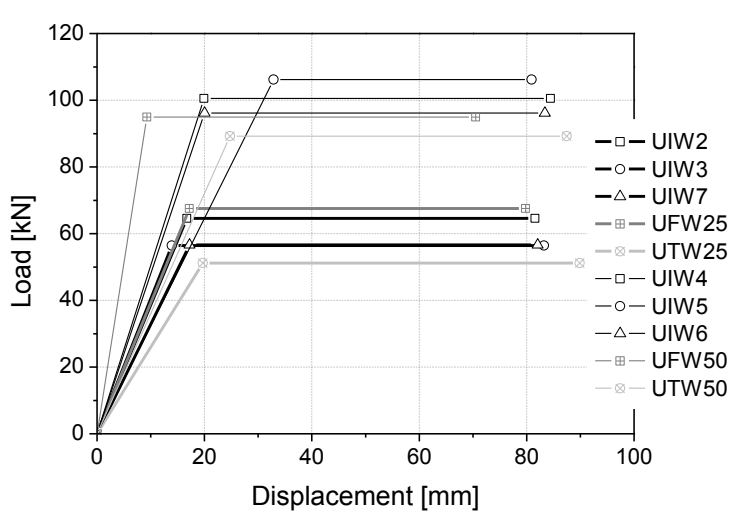

(b)

Fig. 19 Bilinear curves of walls tested: (a) method used to obtain bilinear; (b) bilinear idealizations

\subsubsection{Evaluation of initial stiffness and stiffness degradation}

According to European Standard ISO 21581 (2010), the lateral stiffness of the walls may be calculated according to eq. 1 :

$$
K_{1, \text { in }}=\frac{0,3 F_{\max }}{\delta_{40 \% F_{\max }}-\delta_{10 \% F_{\max }}}
$$

where $\delta_{40 \% F_{\max }}$ and $\delta_{10 \% F_{\max }}$ are the displacement values obtained in the envelope curve at 40 and $10 \%$ of the maximum load $\left(F_{\max }\right)$ respectively.

The consideration of the initial displacement corresponding to $10 \%$ of the maximum force should be associated to the need of overcoming some type of initial nonlinearity. It should be noticed that in this case of traditional timber frame walls, considerable nonlinear behaviour to very small values of lateral drift were recorded, which should be associated to the accommodations that the wall connections encounter at the beginning of the tests. In this work, to overcome the initial nonlinear behaviour and to obtain a more adjusted linear branch to the monotonic envelops, it was decided 
to calculate the secant stiffness taking into account the origin and the point corresponding to $40 \%$ of the maximum load, $\left(\mathrm{K}_{1, \mathrm{~s}+}\right)$. All values of stiffness were calculated for the initial cycle.

The values of the secant stiffness, $\mathrm{K}_{1, \mathrm{in}+}$, and $\mathrm{K}_{1, \mathrm{s+}}$ are shown in Table 3 . As expected, the values found for the secant stiffness $K_{1, s+}$ considering a secant stiffness from the origin up to $40 \%$ of the maximum load are greater than those of the standard initial stiffness because it softens the effect of the initial nonlinearity due to the initial adjustment of the traditional walls connections. The values are nonetheless of the same order.

The three UIW25 walls had an average initial stiffness of $3.03 \mathrm{kN} / \mathrm{mm}$ (c.o.v. $10.17 \%$ ). The UIW50 walls experienced a higher variation, with an initial stiffness of $3.75 \mathrm{kN} / \mathrm{mm}$ (c.o.v. $18.42 \%$ ). It is observed that stiffness varied among the three types of walls tested. This variation can be attributed to a varying stiffness of the timber elements of the walls, to imperfections in the assembling of the timber frame, mainly possible clearances in the connections, and to the variation in the stiffness of the masonry infill, as a great variation in terms of results was reported when characterizing the materials of the walls.

The vertical pre-compression influences the lateral stiffness. It is observed that there is an increase on the stiffness as the vertical pre-compression increases. The increase is particularly relevant in case of lath and plaster walls. This is in agreement with past results obtained also in traditional timber walls submitted to lateral cyclic loading (Vasconcelos and Lourenço 2009). The timber walls present the lower values of initial stiffness, which should be associated to the absence of infill.

Comparing with other experimental works performed on traditional timber frame walls with and without infill, Gonçalves et al. (2012) found significantly lower values of stiffness for traditional Portuguese frontal walls, namely $0.7 \mathrm{kN} / \mathrm{mm}$ for timber-frame walls with a vertical load of $75 \mathrm{kN}$ and $2.2 \mathrm{kN} / \mathrm{mm}$ for masonry infill walls. The differences could be attributed to the different workmanship (which could lead to higher clearances in timber-frame walls), different materials and different infill properties.

Comparing the results with traditional timber frame walls from Haiti (Vieux-Champagne et al., 2014), the initial stiffness of the walls is significantly lower for Haitian walls, but this is easily understandable since the connections are weaker and very few elements are 
continuous, the connections are guaranteed only by means of nails. It would appear (no definite results have been published at the time of writing) that the initial stiffness of timberframe walls filled with stones is approximately $0.8 \mathrm{kN} / \mathrm{mm}$.

Table 3 Values of initial stiffness for tested walls

\begin{tabular}{ccc}
\hline \hline WALL & $\begin{array}{c}\mathbf{K}_{\mathbf{1}, \mathbf{i n}+} \\
{[\mathrm{kN} / \mathrm{mm}]}\end{array}$ & $\begin{array}{c}\mathbf{K}_{\mathbf{1 , s +}} \\
{[\mathrm{kN} / \mathrm{mm}]}\end{array}$ \\
\hline \hline UIW2 & 2.98 & 3.86 \\
UIW3 & 3.36 & 4.05 \\
UIW7 & 2.75 & 3.29 \\
\hline Average UIW25 & 3.03 & 3.73 \\
C.O.V. & $10.17 \%$ & $10.59 \%$ \\
\hline UIW4 & 4.42 & 5.05 \\
UIW5 & 3.04 & 3.23 \\
UIW6 & 3.79 & 4.80 \\
\hline Average UIW50 & 3.75 & 4.36 \\
C.O.V. & $18.42 \%$ & $22.63 \%$ \\
\hline UFW25 & 3.24 & 3.93 \\
UFW50 & 7.99 & 10.21 \\
\hline UTW25 & 2.14 & 2.60 \\
\hline UTW50 & 3.16 & 3.60 \\
\hline \hline
\end{tabular}

In order to evaluate the degradation of stiffness experienced by the walls during the cyclic tests, cyclic stiffness was calculated for each cycle considering the average of the slopes of the line connecting the origin and the two points of loading corresponding to the maximum (positive and negative) displacements. Due to the accommodations that occur in the wall for low values of drifts already mentioned, values of cyclic stiffness calculated for drift values lower than $0.15 \%$ are not considered reliable and thus they are not represented here.

The variation of the cyclic stiffness for increasing lateral drifts is presented in Fig. 20a. The lateral drift is calculated as the ratio between the lateral top displacement and the height at which the lateral load is applied. It is seen that the cyclic stiffness presents steep stiffness degradation for early lateral drifts. The major stiffness degradation occurs for lateral drifts lower than $1 \%$. It is seen also that the cyclic stiffness decreases exponentially and approaches very low residual stiffness for increasing lateral drifts. In case of walls submitted to the highest levels of pre-compression load, it is possible to differentiate the values of stiffness degradation among the distinct types of walls. This is not possible in case of the lower pre-compression load for which the stiffness degradation is similar for all walls. Besides, it is noticed that the residual cyclic stiffness is comparable for both 
pre-compression load levels. The steep degradation of the cyclic stiffness is associated to the strong non-linear behaviour evidenced by the walls from early stages of lateral drifts.

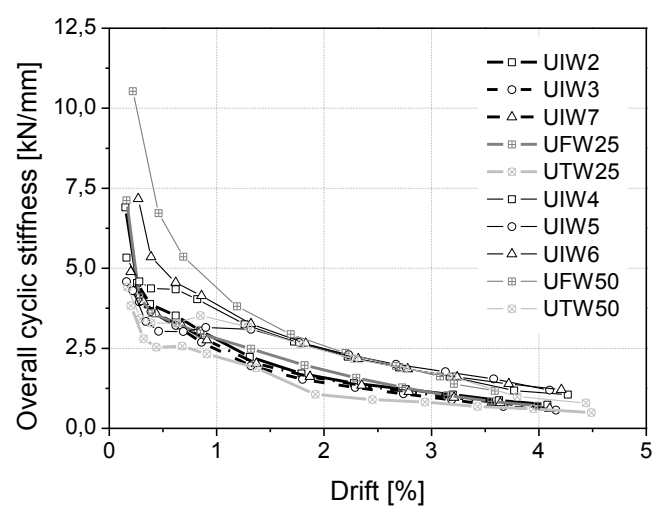

(a)

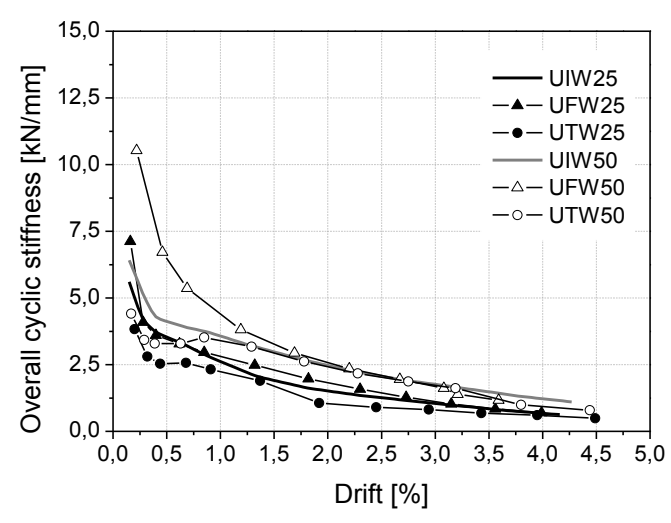

(b)

Fig. 20 Overall cyclic stiffness: (a) values for all walls; (b) average values for each wall type

Timber walls exhibit the lowest cyclic stiffness, but for higher values of drift the results of the three wall types are comparable. The homogenization of the values occurs after a drift of $1.5 \%$ for the higher vertical load level and after a drift of $3.5 \%$ for the lower vertical load level. However, the degradation rate is different from UTW25 walls to walls UIW25 and UFW25. In walls, the cyclic stiffness reached an almost constant value after a value of drift of $1.85 \%$, whereas walls UIW25 and UFW25, continued to lose stiffness for increasing values of drift. UTW50 wall instead, degraded its stiffness in a way more similar to what happened for the infill walls, even though both timber frame walls exhibited an early stiffness degradation higher than what observed in infill walls. This was probably due to the fact that the absence of infill caused the frame to loosen more for low values of drift.

It is clearly seen that the amount of vertical load directly influences the cyclic response of the walls. The higher vertical load leads to higher values of cyclic stiffness (Fig. 20b) up to lateral drift lesser than $3.5 \%$, after which stiffness starts to be comparable for the two load levels. For lateral drifts up to $2.5 \%$, the cyclic stiffness was almost the double for the highly loaded walls.

Comparing the values of cyclic stiffness for the different wall typologies, for the lower vertical load level, lath and plaster walls had an increase of $27 \%$ and $12 \%$ for low and high values of drifts respectively when compared to masonry infill walls. Contrarily, timber frame walls saw a decrease in their values of cyclic stiffness by $32 \%$ and $22 \%$ for low and high 
values of drift respectively when compared to half-timbered walls. The same trend was observed for the higher vertical load level: lath and plaster walls increased their values by $64 \%$ and $6 \%$ respectively while timber frame walls decreased by $31 \%$ and $28 \%$.

Comparing the results with similar ones performed on traditional scaled Portuguese timberframe walls (Vasconcelos et al., 2013) the values of cyclic stiffness for low values of drift are higher (between 12 and $14 \mathrm{kN} / \mathrm{mm}$ ), but this could be attributed to the different geometry which presents a higher number of bracing members. The degradation of stiffness is however similar, with very low values of stiffness for higher values of drift.

Dutu et al. (2013) tested a similar timber frame wall without diagonal elements. The infill wall exhibited a similar stiffness degradation, with a value of stiffness of $4.7 \mathrm{kN} / \mathrm{mm}$ for drift values of approximately $0.6 \%$ and a residual stiffness of approximately $1.2 \mathrm{kN} / \mathrm{mm}$ for drift values of approximately $4.8 \%$.

\subsubsection{Evaluation of ductility}

Ductility is an important factor for the evaluation of the seismic behaviour of structures in seismic regions, as it is directly related to the ability of the structure to deform nonlinearly without significant loss of strength. Displacement ductility is defined here as the ratio between the ultimate displacement $\left(d_{u}\right)$ and the yield displacement $\left(d_{y}\right)$ defined in the equivalent bilinear diagram.

Ductility $\mu_{1}$ was calculated using the values of secant stiffness calculated above considering the slope of the curve between the origin and $40 \%$ of the maximum load. Once again, only the portion of the bilinear curve corresponding to positive values of displacement was considered. As far as ductility is concerned, some variation is found when the typology of the walls is considered. Timber frame walls with infill present higher values of ductility, see Table 4. An average ductility of 5.20 (c.o.v. 12.81\%) was found for UIW25 walls, while for UIW50 walls an average ductility of 3.62 (c.o.v. $27.82 \%$ ) was obtained.

Besides, it is seen that timber frame walls without infill presented lower values of ductility for both load cases when compared to infill timber frame walls. This means that the filling of the timber frame walls leads to improvement of the ductility as it result from the change on the resisting mechanism from shear to flexure or a mixed mode of shear and flexure mode, as in case of infill 
timber frame walls submitted to the highest level of pre-compression. It should be noticed that the lower values of ductility found for timber frame walls are associated to considerable higher levels of damage. In all cases, the walls are repairable after the imposition of the maximum lateral drift, but in case of timber frame walls without infill, it is needed to replace some timber elements. This appears to indicate that the presence of infill improves the seismic behaviour of the walls as improve ductility with a lower level of damage.

Table 4 Values of ductility for tested walls

\begin{tabular}{|c|c|c|c|}
\hline WALL & $\mu_{1+}$ & $\mu_{1+\text {,avg }}$ & C.O.V. \\
\hline UIW2 & 4.88 & & \\
\hline UIW3 & 5.97 & 5.20 & $12.81 \%$ \\
\hline UIW7 & 4.76 & & \\
\hline UIW4 & 4.24 & & \\
\hline UIW5 & 2.46 & 3.62 & $27.82 \%$ \\
\hline UIW6 & 4.17 & & \\
\hline UFW25 & 4.65 & & \\
\hline UFW25* & 4.11 & & \\
\hline UFW50 & 7.58 & & \\
\hline UTW25 & 4.57 & & \\
\hline UTW50 & 3.53 & & \\
\hline UTW50* & 2.90 & & \\
\hline
\end{tabular}

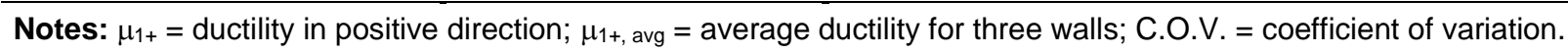

* without ultimate displacement limitation

Apart from lath and plaster walls, it should be stressed that the ductility of the walls tend to decrease with the level of pre-compression, which results from the higher importance of the shear resisting mechanism on the lateral response of the walls. This behaviour is also characteristic of other types of walls, including stone and brick masonry (Vasconcelos and Lourenço 2009).

Similar tests performed on reduced scale infill timber frame walls (Vasconcelos et al. 2013) gave values of ductility ranging from 5.48 to 17.95 , depending on the amount of vertical precompression. However, the geometry and connections type of these walls was significantly different from what tested here. It should be stressed than in general the walls tested did not reached high values of degradation, meaning that the walls could undergo some additional displacements, which could result in higher values of ductility. It was not possible to reach these values due to the limitations on the imposed lateral displacement. 
In any case, when values of ductility and lateral drift obtained in timber frame walls are compared to other shear walls typologies such us brick or block masonry, it is seen that timber frame walls present considerably higher values with repairable damage, presenting considerable advantages over the typologies mentioned.

\subsubsection{Assessment of the ability to dissipate energy}

Besides ductility and lateral drifts, one major parameter used for the assessment of the seismic performance of the seismic behaviour is the ability of a structural element to dissipate energy during cyclic testing. Here, the dissipation of energy per each cycle and the cumulative normalized energy are considered. The energy dissipated by the walls at each cycle, $E_{D}$, is computed by calculating the area enclosed by the loop in the load-displacement diagram and it represents the amount of energy dissipated during the cyclic loading. The energy can be dissipated through friction in the connections, yielding of nails and residual deformation in the wall panel, as observed during the tests.

Fig. 21 reports the graphs of the variation of the cumulative dissipated energy for all walls tested with the two vertical load conditions with the increasing lateral drift. It is observed that the vertical load has an important role on the amount of energy dissipated. The dissipated energy increases with the drift, with a higher trend for the higher vertical load level. This can be related to the higher amount of damage found for this level of vertical pre-compression. In fact, the energy dissipation is always associated to the propagation of damage on a structure.

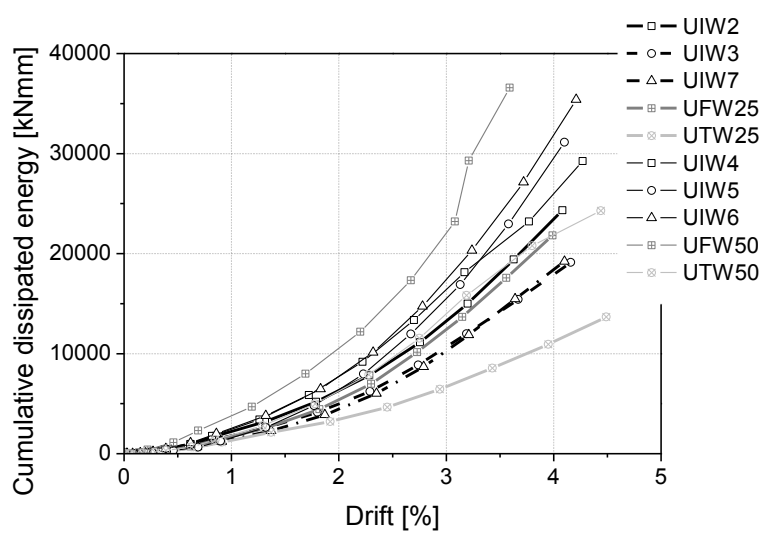

Fig. 21 Energy dissipated in walls, cumulative values 
Notice that infill timber frame walls submitted to the lower pre-compression level behave mainly in rocking from the detachment of the vertical posts from the bottom beams, which in nature is a low dissipative behaviour mode. The cumulative dissipated energy presents an exponential trend. For both load levels, lath and plaster walls had a higher dissipative capacity.

The low values of dissipated energy for timber frame walls (Fig. 21), compared to filled walls, can be attributed to the strong pinching present in this walls, that clearly diminishes the dissipative capacity of the walls. In fact, when comparing the different shape of the hysteretic loops for each wall type (Fig. 22a,b) the strong pinching in timber frame walls is evident, as well as the plateau in the unloading branch of filled walls, which reduces the dissipative capacity of the walls.

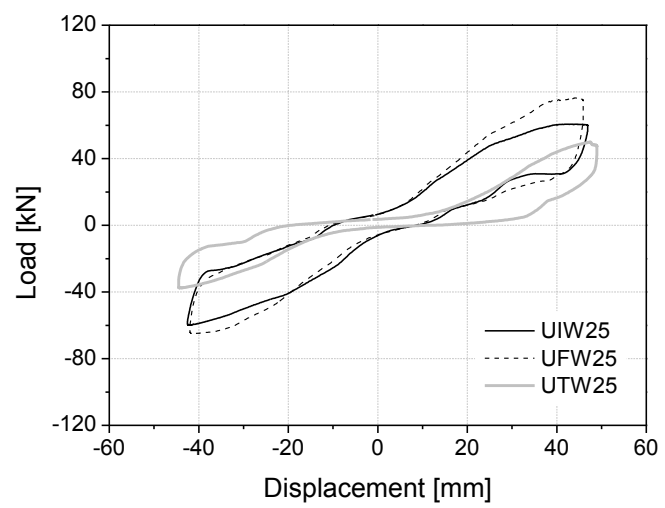

(a)

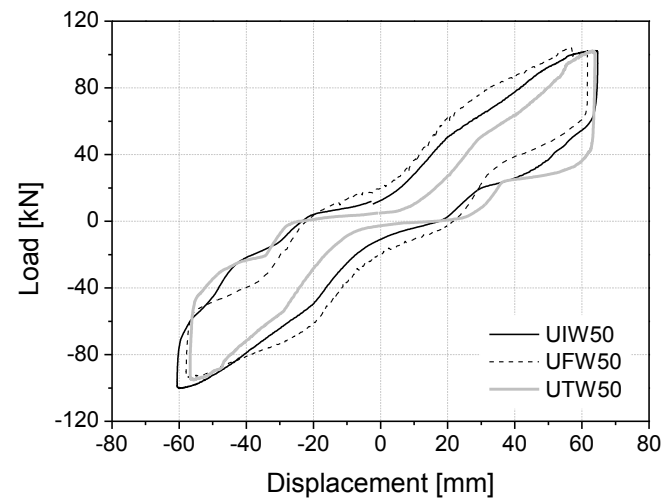

(b)

Fig. 22 Typical hysteretic loops: (a) lower vertical load level at $50.61 \mathrm{~mm}$; (b) higher vertical load level at $70.85 \mathrm{~mm}$

Comparing the total cumulative dissipated energy among the different wall typologies, once again lath and plaster walls exhibited the highest values, gaining $2 \%$ on half-timbered walls for the lower vertical load level and $10 \%$ for the higher. Timber frame walls instead dissipated less energy than half-timbered walls, namely $36 \%$ and $27 \%$ less for the lower and higher vertical load level respectively.

Comparing the results obtained with those from Aktas et al. (2013), the cumulative energy dissipated by the walls is much higher. The Ottoman walls reached values of $12000 \mathrm{kNmm}$, values much lower than what encountered in this study, but in that case the connections are mainly notched or nailed, therefore they dissipate less energy.

Dutu et al. (2013) reported a dissipated energy of $8000 \mathrm{kNmm}$ for the last cycle of the test, corresponding to a drift of approximately $4.8 \%$, comparable to what observed for infill 
timber walls subjected to the higher vertical pre-compression (Poletti 2013). The total dissipated energy reported by the authors is $37690 \mathrm{kNmm}$ for infill walls, comparable to the values presented in Fig. 21, and 2940kNmm for walls without infill, pointing out the influence of infill in the dissipative capacity.

Ruggieri and Zinno reported a value of dissipated energy for the final cycle in the positive direction (drift of approximately $3 \%$ ) of $3982 \mathrm{kNmm}$ for infill timber frame walls of the baraccata system, which assuming an approximately symmetrical behaviour, is comparable to what found for the walls tested (Poletti 2013).

\subsubsection{Equivalent viscous damping}

Equivalent viscous damping is correlated to energy dissipation. Damping is the process by which vibration steadily diminishes in amplitude (Chopra 1995). Damping diminishes the energy of the structure through various mechanisms, such as, for the present case, friction in the connections and opening and closing of cracks and gaps. Equivalent viscous damping is calculated according to eq. 2 (Magenes and Calvi 1997):

$$
\zeta_{e q}=\frac{E_{d}}{2 \pi\left(E_{e}^{+}+E_{e}^{-}\right)}
$$

where $E_{d}$ is the dissipated hysteretic energy discussed above, $E_{e}{ }^{+}$and $E_{e}^{-}$are the elastic energies of an equivalent viscous system calculated at the maximum displacement in each loop for the positive and negative direction of loading respectively.

It should be stressed that considerable variation of EVDR among the walls (Fig. 23a). For low values of lateral drift there is a great variation on the EVDR in walls UIW25, being lower for lateral drift greater than $3 \%$. A similar behaviour was observed even for walls UIW50, for lateral drifts greater than $2 \%$.

EVDR is influenced by the presence of infill and the amount of vertical load (Fig. 23b). For the lower vertical load level, it appears that the type of infill does not influence this parameter, but the absence of infill increases the values of EVDR from a constant value of 0.10 for infill walls to an almost constant value of 0.12 for timber walls. For the higher vertical load level, this trend is not so clear. Lath and plaster walls present the higher values for low values of drift and then EVDR values 
decrease and become comparable to those of timber frame walls. This means that, although timber walls present lower values of maximum load, stiffness and ductility, they have a comparable damping capacity for high values of drift due to the shear behaviour. In fact, only analysing the loops of infill walls vs. timber frame walls it is possible to observe how the loops in timber frame walls are more curved, so the damping for these walls is higher.

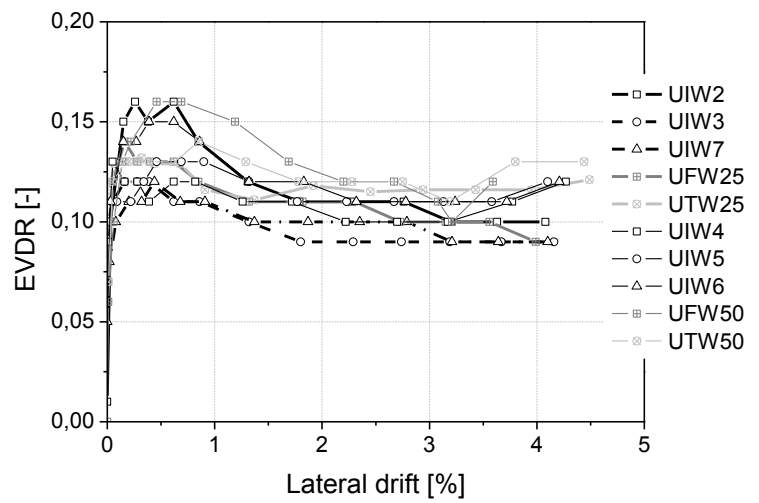

(a)

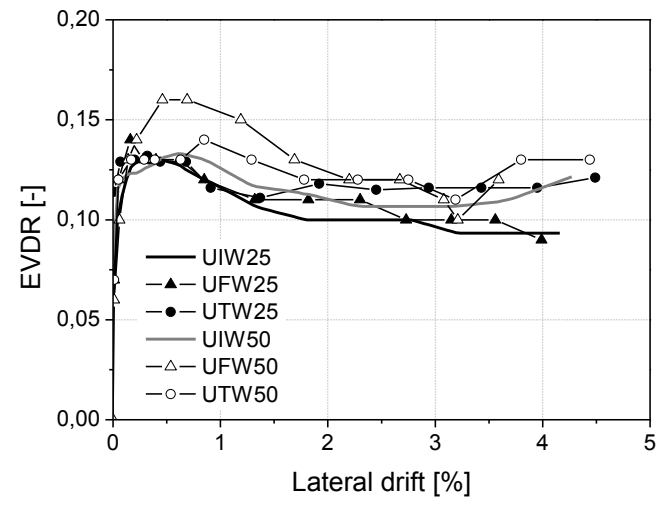

(b)

Fig. 23 Values of EVDR: (a) all walls; (b) average values according to wall typology

For infill walls, there is no increase of EVDR as the damage progresses, while a minimal increase can be observed for timber frame walls without infill. This different behaviour is connected once again to the different global behaviour of the walls. As it was observed in (Magenes and Calvi 1997), for walls with a flexural behaviour the values of EVDR are almost constant, while for a diagonal shear cracking response the values are usually increasing with an increase of drift and damage accumulated.

Gonçalves et al. (2012), on similar traditional Portuguese frontal walls, obtained values of viscous damping for low values of drift of $0.17-0.20$ for infill walls and $\mathbf{0 . 1 9 - 0 . 2 0}$ for timberframe walls. The values then decreased to $0.11-0.13$ and $0.10-0.11$ respectively, confirming the trend of having higher values for low drifts, then decreasing values with an increase in viscous damping in some cases for ultimate values of drift since the wall is rocking. Vieux-Champagne et al. (2014) obtained similar values, namely 0.15 for infill walls and 0.17 for timber frame walls with no infill with values approximately constant throughout the test. Dutu et al. (2013) obtained values varying between 0.8 and 0.16 , with values increasing with damage accumulation. 


\section{Conclusions}

Aiming at analysing the lateral behaviour of timber frame walls, characteristic of ancient construction in Portugal, and that are comparable to other timber frame walls found in several countries, an experimental campaign was designed based on static cyclic tests. Distinct parameters were considered, namely typology for the infill and vertical pre-compression load. Three distinct solutions were adopted: (1) brick masonry infill; (2) lather and plaster; and (3) no infill. Besides, two vertical pre-compression levels were considered for each wall type.

From the detailed analysis of the experimental results it is possible to conclude that:

- The presence of infill changes considerably the response of the walls in terms of predominant resisting mechanism, ranging from a predominant flexural or mixed shear/flexural behaviour of infill timber frame walls to a shear predominant resisting mode for timber frame walls with no infill;

- The increase on the vertical pre-compression load results also on the change on the lateral behaviour of infill walls. Higher values of vertical pre-compression results in the mixed flexural/shear resisting mechanism, whereas in case of walls submitted to the lowest precompression, flexural/rocking mechanism predominates. In case of timber frame walls with no infill, shear resisting mechanism prevails for bot levels of vertical pre-compression.

- The vertical load level influences also the load capacity, stiffness, ductility and energy dissipation of the walls. A higher vertical load leads to higher values of seismic parameters. Moreover, a higher pre-compression accentuates damages in infill walls, while in timber frame walls damage patterns did not depend on the amount of vertical load applied.

- Timber frame walls present lower load capacity, stiffness and ductility when compared to infill walls, but the damping capacity is slightly greater, due to their distinct response;

- The traditional infill timber frame walls presents in general very good deformation capacity, exhibiting higher lateral drifts with controlled damage. In case of timber frame walls with no infill the same lateral drifts have associated high level of damage, mainly concentrated at the central connections. The absence of infill promotes the free functioning of the walls, 
which results in much higher shear deformations and higher damage due to shear deformation of the connections.

- The application of infill in traditional timber walls can, in a certain extent, be viewed as a strengthening strategy as it improves the lateral cyclic performance and controls the damage progression at the connections due to the confining effects.

\section{Acknowledgements}

The authors would like to acknowledge Eng. Filipe Ferreira and A.O.F. (Augusto Oliveira Ferreira \& C Lda.) for their expertise and collaboration in the construction of the wall specimens.

The first author would also like to acknowledge the Portuguese Science and Technology Foundation (FCT) for its financial support through grant SFRH / BD / 61908 / 2009.

\section{References}

Aktaş Y.D., Akyüz U., Türer A., Erdil B., Güçhan N.S. (2013). Seismic Resistance Evaluationof Traditional Ottoman Timber-Frame Hımış Houses: Frame Loadings and Material Tests. Earthq Spectra, DOI: http://dx.doi.org/10.1193/011412EQS011M

ASTM E519-02 (2003). Standard Test Method for Diagonal Tension (Shear) in MasonryAssemblages. ASTM International, United States.

Bianco A (2010) The 'casa baraccata'. Guide to design and rehabilitation site (in Italian). GB EditoriA, Rome

Bostenaru MD (2004) Timber frame house in the "border triangle" (Fachwerkhaus im Dreiländereck). Housing report, World housing encyclopedia (available at http://www.worldhousing.net/WHEReports/wh100106.pdf)

Chopra AK (1995) Dynamics of structures. Prentice Hall, Englewood Cliffs, New Jersey

Cóias V (2007) Structural rehabilitation of old buildings (in Portuguese). ARGUMENTUM, GECoPRA, Lisbon 
Cruz H, Machado S, Rodrigues M, Monteiro G (1997) Wood for construction. Pinho Bravo for structures (in Portuguese). Ficha M2, LNEC

Dinwoodie JM (2000) Timber: its nature and behaviour. Second Edition. CRC Press, ISBN-10: 0419235809

Doğangün A, Tuluk OI, Livaoğlu R, Acar R (2006) Traditional wooden buildings and their damages during earthquakes in Turkey. Engineering Failure Analysis 13:981-996

Duţu A, Ferreira JG, Gonçalves A, Covaleov (2012) A components interaction in timber framed masonry structures subjected to lateral forces. Constructii 1: 62-67 (Available at http://constructii.incerc2004.ro/Archive/2012-1/Constructii_2012_Vol.13_No.1_ID2012130106.pdf)

Duţu A, Sakata H, Yamazaki Y (2013) Experimental study on timber framed masonry structures. In Proceedings of the 1st International Symposium on Historic Earthquake-Resistant Timber Frames in the Mediterranean Region (H.Ea.R.T.2013), November 4-5, University of Calabria, ITALY

EN 408 (2003) Timber structures - Structural timber and glued laminated timber - Determination of some physical and mechanical properties. European Committee for Standardization (CEN), Brussels, Belgium

EN 772-1 (2000). Methods of test for masonry units. Determination of compressive strength. European Committee for Standardization (CEN), Brussels, Belgium

EN 1015-11 (1999) Determination of flexural and compressive strength of hardened mortar. European Committee for Standardization (CEN), Brussels, Belgium

EN 1052-1 (1999) Methods of test for masonry - Part 1: Determination of compressive strength. European Committee for Standardization (CEN), Brussels, Belgium

Eurocode 1 (2002) EN1991-1-1:2002. Actions on structures-part 1-1: general actions-densities, self-weight, imposed loads for buildings. European Committee for Standardization (CEN), Brussels, Belgium

Gonçalves A, Ferreira J, Guerreiro L, Branco F (2012) Experimental characterization of Pombalino "frontal" Wall cyclic behaviour. In: Proceedings of the 15th World Conference on Earthquake Engineering (15WCEE), Lisbon 
Götz KH, Hoor D, Möhler K, Natterer J (1993) Building in bois (in French). Press Polytechniques et Universitaires Romandes, Lausanne, Switzerland

Gulkan P, Langenbach R (2004) The earthquake resistance of traditional timber and masonry dwellings in Turkey. In: $13^{\text {th }}$ World Conference on Earthquake Engineering, Paper 2297, Vancouver, Canada

Gülhan D, Güney IÖ (2000) The behaviour of traditional building systems against earthquake and its comparison to reinforced concrete frame systems: experiences of Marmara earthquake damage assessment studies in Kocaeli and Sakarya. In: Proceedings of Earthquake-safe: Lessons to be Learned from Traditional Construction, Istanbul, Turkey

ISO 21581 (2010) Timber structures - Static and cyclic lateral load test method for shear walls. International Organization for Standardization (ISO), Geneva, Switzerland

Kouris L, Kappos A J (2012) Detailed and simplified non-linear models for timber-framed masonry structures. J Cult Herit 13(1):47-58

Langenbach R (2007) From "Opus Craticium" to the "Chicago Frame": Earthquake-Resistant Traditional Construction. Int J Archit Herit 1(1):29-59

Langenbach R (2009) DON'T TEAR IT DOWN! Preserving the earthquake resistant vernacular architecture of Kashmir. UNESCO, New Delhi

Magenes G, Calvi GM (1997). In-plane seismic response of brick masonry walls. Earthq Eng and Struct Dyn 26:1091-1112

Mascarenhas J (2004) Construction systems - V (in Portuguese). Livros Horizonte, Lisbon

Meireles H, Bento R, Cattari S, Lagomarsino S (2012) A hysteretic model for "frontal" walls in Pombalino buildings. Bull Earthq Eng, 10(5): 1481-1502.

Santos S (1997) Tests of Pombalino walls (in Portuguese). Technical № 15/97-NCE, LNEC, Lisbon

Mendes N, Lourenço PB (2010) Seismic Assessment of Masonry "Gaioleiro" Buildings in Lisbon, Portugal. J Earthq Eng 14(1):80 - 101

Piazza M, Tomasi R, Modena R (2005) Timber structures (in Italian). Biblioteca Tecnica Hoepli, Milan, Italy 
Poletti E (2013) Characterization of the seismic behaviour of traditional timber frame walls. PhD Thesis, University of Minho, Portugal (available online at http://hdl.handle.net/1822/28845)

Ruggieri N, Zinno R (2013) Behaviour of the Borbone Constructive System under Cyclic Loading. Preliminary Report. In Proceedings of the 1st International Symposium on Historic EarthquakeResistant Timber Frames in the Mediterranean Region (H.Ea.R.T.2013), November 4-5, University of Calabria, ITALY

Salavessa E (2011) Historical timber-framed buildings / characterization and acquaintance. In: Proceedings of SHATIS'11 International Conference on Structural Health Assessment of Timber Structures, Lisbon, Portugal

Tampone G (1996) The rehabilitation of timber structures (in Italian). Libreria Tecnica Hoepli, Milan, Italy

Tomaževic M (1999) Earthquake-resistant design of masonry buildings. Imperial College Press, London

Tomaževič M, Lutman M, Petkovič L (1996) Seismic behaviour of masonry walls: experimental simulation. J Struct Eng 122(9):1040-1047

Tsakanika-Theohari E (2006) The Structural Role of Timber in Palatial Architecture of Minoan Crete (in Greek). Ph.D. Thesis, National Technical University of Athens (NTUA)

Vasconcelos G, Lourenço PB (2009) In-Plane Experimental Behavior of Stone Masonry Walls under Cyclic Loading. J Struct Eng 135(10):1269-1277

Vasconcelos G, Poletti E, Salavessa E, Jesus A, Lourenço P, Pilaon P (2013) In-plane shear behaviour of traditional timber walls, Eng Struct 56:1028-1048

Vieux-Champagne F, Sieffert Y, Grange S, Polastri A, Ceccotti A, Daudeville L (2014) Experimental analysis of seismic resistance of timber-framed structures with stones and earth infill. Eng Struct 69:102-115

Vintzileou E, Zagkotsis A, Repapis C, Zeris Ch (2007) Seismic behaviour of the historical structural system of the island of Lefkada, Greece. Constr Build Mat, 21: 225-236 